\title{
Diabetes-induced hepatic oxidative stress: a new pathogenic role for glycated albumin
}

\author{
Jessica Patche ${ }^{\mathrm{a}}$, Dorothée Girard ${ }^{\mathrm{a}}$, Aurélie Catan ${ }^{\mathrm{a}}$, Florence Boyer ${ }^{\mathrm{a}}$, Anthony Dobi ${ }^{\mathrm{a}}$, \\ Cynthia Planesse $^{\mathrm{a}}$, Nicolas Diotel ${ }^{\mathrm{a}}$, Alexis Guerin-Dubourg ${ }^{\mathrm{a}, \mathrm{b}}$, Pascal Baret ${ }^{\mathrm{a}}$, Susana B. Bravo ${ }^{\mathrm{c}}$, \\ Beatriz Paradela-Dobarro ${ }^{c}$, Ezequiel Álvarez ${ }^{c}$, M. Faadiel Essop ${ }^{\mathrm{d}}$, Olivier Meilhac ${ }^{\mathrm{a}, \mathrm{e}}$, \\ Emmanuel Bourdon ${ }^{\mathrm{a}, *, 1}$, Philippe Rondeau ${ }^{\mathrm{a}, *, 1}$ \\ a Université de La Réunion, INSERM, UMR 1188 Diabète athérothrombose Thérapies Réunion Océan Indien (DéTROI), plateforme CYROI, Sainte-Clotilde, \\ France \\ ${ }^{\mathrm{b}}$ Centre Hospitalier Gabriel Martin, Saint-Paul de La Réunion, France \\ c Proteomic Unit and Instituto de Investigación Sanitaria de Santiago de Compostela (IDIS), Hospital Clínico Universitario de Santiago, Santiago de \\ Compostela, Spain \\ d Cardio-Metabolic Research Group (CMRG), Department of Physiological Sciences, Stellenbosch University, Stellenbosch, South Africa \\ e CHU de La Réunion, Centre d'Investigation Clinique, Saint-Denis F-97400, France
}

\begin{abstract}
A B S T R A C T
Increased oxidative stress and advanced glycation end-product (AGE) formation are major contributors to the development of type 2 diabetes. Here plasma proteins e.g. albumin can undergo glycoxidation and play a key role in diabetes onset and related pathologies. However, despite recent progress linking albumin-AGE to increased oxidative stress and downstream effects, its action in metabolic organs such as the liver remains to be elucidated. The current study therefore investigated links between oxidative perturbations and biochemical/structural modifications of plasma albumin, and subsequent downstream effects in transgenic $\mathrm{db} / \mathrm{db}$ mouse livers and HepG2 cells, respectively. Our data reveal increased oxidative stress biomarkers and lipid accumulation in plasma and livers of diabetic mice, together with albumin glycoxidation. Purified mouse albumin modifications resembled those typically found in diabetic patients, i.e. degree of glycation, carbonyla-tion, AGE levels and in terms of chemical composition. Receptor for AGE expression and reactive oxygen species production were upregulated in $\mathrm{db} / \mathrm{db}$ mouse livers, together with impaired proteolytic, antioxidant and mitochondrial respiratory activities. In parallel, acute exposure of HepG2 cells to glycated albumin also elicited intracellular free radical formation. Together this study demonstrates that AGE-modified albumin can trigger damaging effects on the liver, i.e. by increasing oxidative stress, attenuating antioxidant capacity, and by impairment of hepatic proteolytic and respiratory chain enzyme activities.
\end{abstract}

\section{Introduction}

Diabetes mellitus is an endocrine metabolic disease of increasing incidence and is associated with serious complications contributing to high morbidity and mortality rates [1]. Several metabolic and signaling pathways become dysfunctional and contribute to chronic disorders associated with diabetes. For example, oxidative stress and advanced glycation end-product (AGE) formation have been identified as key mediators of pathophysiology occurring in diabetes [2]. The combination of oxidative stress and AGEs can elicit irreversible tissue and cellular damage associated with diabetes mellitus and related metabolic disorders $[3,4]$. The generation of AGEs is a complex process that initially involves a condensation reaction between circulating proteins and glucose, followed by Amadori rearrangement, cyclization, polymerization, cleavage and oxidation processes $[5,6]$.

The strong implication of AGEs in the pathogenesis of diabetic

\footnotetext{
Abbreviations: 4-HNE, 4-hydroxynonenal; ACB, albumin cobalt binding; AGE, advanced glycation end-product; AOPP, advanced oxidation end-products; DCF, dichlorofluorescein;

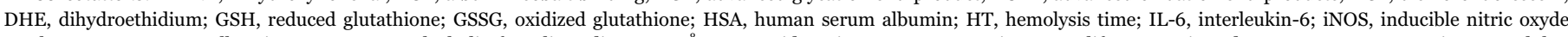

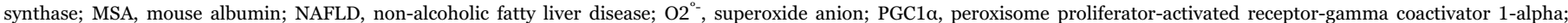
RAGE, receptor for AGE; ROS, reactive oxygen species; SOD (1, 2), superoxide dismutase (1, 2); TrxR, thioredoxin reductase; UPS, ubiquitin proteasome system; WT, wild type

* Correspondence to: UMR DéTROI Inserm 1188 - Université de La RéunionPlateforme CYROI,2, rue Maxime Rivière97490 Sainte-Clotilde.

E-mail addresses: emmanuel.bourdon@univ-reunion.fr (E. Bourdon), rophil@univ-reunion.fr (P. Rondeau).

${ }^{1}$ These authors contributed equally to this work.
} 
complications is mediated by its interaction with specific receptors (RAGE) and the subsequent generation of intracellular oxidative stress, thus triggering irreversible damage to cells and tissues $[7,8]$. The pivotal role played by hyperglycemia-mediated oxidative stress results in weakening of intracellular defense systems that are then unable to counteract the increased reactive oxygen species (ROS) production. When the intracellular defense and/or repair processes fail, proteolytic mechanisms such as the ubiquitin proteasome system (UPS) allow the removal of damaged oxidized protein [9].

The liver is an organ of central metabolic importance where oxidation and detoxifying processes occur at the early stages of many diseases including diabetes. Diabetes mellitus is frequently associated with liver dysfunction leading to abnormal hepatic lipid accumulation, known as non-alcoholic fatty liver disease (NAFLD) [10]. Numerous clinical studies demonstrated that once diabetes-related NAFLD is established, ROS can contribute to the progression of liver fibrosis and cirrhosis [11,12]. Therefore, end-stage liver diseases represent an important cause of mortality in diabetic patients [13,14].

The liver plays a key role in glucose homeostasis and protein metabolism. Due to its role in glycogen storage and glucose production by glycogenesis (in fed state) and gluconeogenesis (in fasting period), respectively, the liver is regarded as the most important regulator of carbohydrate metabolism. The liver also secretes most of plasma proteins, e.g. albumin, the main antioxidant allowing regulation of redox homeostasis and a major target of oxidation and glycation processes [15]. Noteworthy enough, albumin represents the most abundant potential source of circulating AGE [5].

Previous studies demonstrated that streptozotocin-induced diabetic rats $[16,17]$ and transgenic diabetic mouse models [18] exhibit increased hepatic oxidative stress. However, the direct contribution of albumin-AGE to increase oxidative stress in organs such as the liver still remains to be elucidated. Taking advantage of leptin receptordeficient " $\mathrm{db} / \mathrm{db}$ " mice, we here investigated the links between oxidative alterations and biochemical/structural modifications of plasma albumin and evaluated its effects on oxidative stress in both liver and plasma. To gain additional mechanistic insights, we also established an in vitro experimental protocol to assess the deleterious effects of albumin-AGE on HepG2 cells by monitoring major oxidative stress biomarkers.

\section{Material and methods}

\subsection{Animal models}

C57BLKs/J+/Lepr ${ }^{\mathrm{db}}$ mice $(\mathrm{db} /+)$ were obtained from Charles River. Three groups were investigated (males, $\mathrm{n}=10$ per group): wild type C57BLKs+/+(WT), heterozygous C57BLKs/J+/Lepr ${ }^{\mathrm{db}}(\mathrm{db} /+)$ and homozygous or diabetic C57BLKs/J/Lepr ${ }^{\mathrm{db}} / \operatorname{Lepr}^{\mathrm{db}}(\mathrm{db} / \mathrm{db})$ were generated. Animals were housed in a controlled environment, under constant temperature $\left(21^{\circ} \pm 2{ }^{\circ} \mathrm{C}\right)$, humidity $(50 \% \pm 5 \%)$ and 12 -h light-dark cycle. Food and water were available ad libitum. All experimental procedures were conducted in compliance with animal protocols approved by the Animal Ethics Committee of Cyclotron Réunion Océan Indien (CYROI) and by the French Ministry of Higher Education and Research (project \# 01268.01).

\subsection{Measurement of metabolic parameters}

From 4 weeks up to 12 weeks of age, animals were weighted and fasting blood glucose levels were determined weekly using the OneTouch ${ }^{\circledast}$ Ultra Blood Glucose Monitoring System. Then, mice were anesthetized (3\% isoflurane) and euthanized. Blood was collected by cardiac puncture into BD Vacutainer ${ }^{\circledast}$ EDTA tubes and plasma was isolated and stored at $-80{ }^{\circ} \mathrm{C}$ until further analysis. Total proteins, insulin, albumin, fructosamine, triglyceride, total cholesterol, lowdensity lipoprotein and high-density lipoprotein levels in plasma were determined using a clinical biochemistry automate Cobas C501 analyzer (Roche Diagnostic). Carbonyl, thiol, reduced glutathione: oxidized glutathione (GSH:GSSG), advanced oxidation end-products, fluorescent AGE levels, glycated albumin and antioxidant activities in plasma were also determined according to the protocols detailed below. Advanced oxidation end-products (AOPP) level was estimated in plasma samples by spectrophotometry according to Witko-Sarsat et al. method [19]. Plasma insulin was measured with ELISA immunoassay provided by Mercodia (Uppsala, Sweden). The redox status in plasma and liver expressed as a GSH:GSSG ratio was evaluated by using a commercially available assay kit (Abcam [ab138881], Cambridge MA), according to the manufacturer's protocol.

\subsection{Mouse albumin purification, in vitro glycation of HSA and characterization}

Mouse albumin (MSA) was isolated from plasma by ammonium sulphate (AS) precipitation method using a two-step protocol according to a previously published procedure [20]. Briefly, plasma globulins were first removed after addition of ammonium sulphate solution (54\%, pH 7.4) followed by a centrifugation step. Then albumin was isolated after addition of an ammonium sulphate solution $(70 \%, \mathrm{pH}$ 7.4), resuspended in $0.1 \mathrm{M}$ sodium phosphate ( $\mathrm{pH} 7.4$ ) and concentrated by ultrafiltration.

Glycated human serum albumin samples were prepared as previously described [21] by incubating filtered solutions of $0.6 \mathrm{mM}$ HSA without (HSA) or with $2 \mathrm{mM}$ methylglyoxal (HSA-AGE) in PBS, $\mathrm{pH}$ 7.4, under sterile conditions and nitrogen gas in capped vials at $37^{\circ} \mathrm{C}$ for four days. The measurement of final concentration of MSA, HSA and HSA-AGE was performed by using bicinchoninic acid assay (BCA).

Albumin samples were characterized by assessing glycation, oxidation, fluorescent tryptophan emission, fluorescent AGE, thiol, carbonyl levels, average molecular mass and ACB index. The glycation levels of mouse and human albumin were determined by using boronate affinity chromatography [22]. Oxidative modifications were analyzed by native gradient polyacrylamide gels (4-15\% of acrylamide) [23]. The determination of fluorescent AGE level in albumin samples and also in mouse plasma was performed using a FluoroMax -4 (Horiba) spectrofluorometer at $350 / 450 \mathrm{~mm}$ [24]. Tryptophan emission spectra were measured on purified MSA and HSA samples in the $260-500 \mathrm{~nm}$ range ( $270 \mathrm{~nm}$ of excitation wavenumber) as described in previous studies $[23,24]$. Carbonylated proteins and thiol group levels in albumin samples, mouse plasma and/or liver tissues were determined using respectively a spectrophotometric assay and Ellman's assay according to previously published procedures [24]. Glycation of serum albumin from mouse and human was analyzed by matrix-assisted laser desorption/ionization time-of-flight mass spectrometry (MALDI-TOF-MS) for mass shift determination and for AGE-modified peptides exploration, as previously described [25]. The albumin cobalt binding (ACB) test reported by Bar-Or et al. was originally designed to detect ischemia modified albumin (IMA) in patients with ischemia. This assay based on the reduced binding affinity of the plasmatic mouse albumin for metal ions (Cobalt, CoII) was already well described [26].

\subsection{Culture of HepG2 hepatoma cells}

HepG2 hepatoma cells were cultured in completed DMEM medium (10\% FBS, penicillin $(100 \mathrm{U} / \mathrm{ml})$, streptomycin $(100 \mathrm{U} / \mathrm{ml})$ and $\mathrm{L}-$ glutamine $(2 \mathrm{mM}))$. Cells were grown in a $5 \% \mathrm{CO}_{2}$ incubator at $37^{\circ} \mathrm{C}$. HepG2 cells were cultured $24 \mathrm{~h}$ with DMEM containing 1\% FBS in 96well plates (10 000 cells/well) (for MTT, DHE and DCF-DA assays) or in 6-well plates (300 000 cells/well) (for antioxidant and proteasome activities or RNA extraction) and treated overnight with HSA, HSAAGE $(50 \mu \mathrm{M})$ or PBS buffer (control). 


\subsection{Cellular proliferation and oxidative stress assays}

The MTT assay was chosen to evaluate the effect of modified HSAAGE on HepG2 cells proliferation. $20 \mu \mathrm{L}$ of MTT dye $(5 \mathrm{mg} / \mathrm{ml})$ was added into each well followed by $4 \mathrm{~h}$ of incubation. After discarding the media, $150 \mu \mathrm{L}$ of dimethylsulfoxide (DMSO) was added and plates were agitated $(30 \mathrm{~min})$ to solubilize dark blue formazan crystals. Absorbance was read at $595 \mathrm{~nm}$ wavelength. A well containing DMSO alone was used as blank.

Intracellular oxidative stress of HepG2 cells was evaluated by using dichlorofluorescein diacetate (DCFH-DA) and dihydroethidium (DHE) probes as described in a previous work [24]. Dihydroethidium (DHE) allows superoxide production monitoring whereas DCF detects intracellular hydrogen peroxide [27]. Results were expressed as the percentage of fluorescence with respect to the control.

\subsection{Real-time qPCR analysis for gene expression}

Total RNA was extracted from liver tissues (12-week time point) or cell cultures using Trizol reagent (Invitrogen). $6 \mu \mathrm{g}$ of RNA was reversed transcripted to cDNA using Random primers (Sigma) and Moloney Murine Leukemia Virus (MMLV, Invitrogen). The cDNA was amplified by PCR on an ABI PRISM 7000 thermal cycler (Applied Biosystems) using the SYBR green master-mix (Eurogentec) and specific murine and human primers (Supplemental Table S1, Eurogentec). Each PCR cycle was conducted for $15 \mathrm{~s}$ at $95{ }^{\circ} \mathrm{C}$ and $1 \mathrm{~min}$ at $60^{\circ} \mathrm{C}$. RNA amounts were calculated using relative standard curves for each mRNA of interest and GAPDH gene as reference. Normalization to GAPDH was conducted to account for variability in quality and concentration of total RNA, and RT efficiency. The results were analyzed using ABI Prism 7000 SDS software.

\subsection{Protein isolation from tissues or HepG2 cells}

About $120 \mathrm{mg}$ of liver tissues previously collected and stored at $-80{ }^{\circ} \mathrm{C}$ were homogenized with a TissueLyser II (Qiagen) in a phosphate buffer $\left(\mathrm{KH}_{2} \mathrm{PO}_{4}(100 \mathrm{mM})\right.$, DTT $(1 \mathrm{mM})$, and EDTA ( $2 \mathrm{mM}), \mathrm{pH} 7.4)$. After centrifugation $(5000 \mathrm{~g} / \mathrm{min}$, for $10 \mathrm{~min})$, the supernatant was used for protein quantification, carbonyl, Westernblot analysis and enzymatic assays.

Total HepG2 cells proteins were extracted by using the freeze-thaw method of cell lysis. After washing with PBS and scrapping, HepG2 cells were collected and resuspended in phosphate buffer $\left(\mathrm{KH}_{2} \mathrm{PO}_{4}\right.$ (100 mM), DTT (1 mM), pH 7.4) and lysis was performed by 5 cycles of fast freezing in liquid nitrogen and subsequent thawing in $37^{\circ} \mathrm{C}$ water bath. Protein lysates were used for enzymatic assays.

\subsection{Antioxidant, proteasome and citrate synthase activities}

SOD activity was assayed by monitoring the rate of acetylated cytochrome $\mathrm{c}$ reduction by superoxide radicals generated by the xanthine/xanthine oxidase system. Measurements were performed in a reagent buffer (xanthine oxidase, xanthine $(0.5 \mathrm{mM})$, cytochrome $\mathrm{c}$ $(0.2 \mathrm{mM}), \mathrm{KH}_{2} \mathrm{PO}_{4}(50 \mathrm{mM})$, EDTA $\left.(2 \mathrm{mM}), \mathrm{pH} 7.8\right)$ at $25^{\circ} \mathrm{C}$. The specific Manganese-SOD (Mn-SOD) activities were determined in the same condition after incubation of samples with $\mathrm{NaCN}(1 \mathrm{mM})$ which inhibits $\mathrm{Cu} / \mathrm{Zn}$-SOD activities. Assays were monitored by spectrophotometry at $560 \mathrm{~nm}$. SOD activities were calculated using a calibration standard curve of SOD (up to $6 \mathrm{unit} / \mathrm{mg}$ ). Total Mn-SOD and resulting $\mathrm{Cu} / \mathrm{Zn}$-SOD activities were expressed as international catalytic units per mg of proteins.

The total activity of glutathione peroxidase (GPX) activity was determined with cumene hydroperoxide as substrate [28]. The rate of glutathione oxidized by cumene hydroperoxide $(6.5 \mathrm{mM})$ was evaluated by the decreased of NADPH ( $0.12 \mathrm{mM}$ in Tris buffer) at $340 \mathrm{~nm}$ in the presence of $\mathrm{NaCN}(10 \mathrm{mM})$, reduced glutathione $(0.25 \mathrm{mM})$ and glutathione reductase $(1 \mathrm{U} / \mathrm{ml})$ in Tris buffer $(50 \mathrm{mM}, \mathrm{pH}$ 8). GPX activity was expressed as international units per gram of proteins.

The catalase activity assay was carried on $40 \mu \mathrm{g}$ of protein lysate in $25 \mathrm{mM}$ Tris- $\mathrm{HCl}(\mathrm{pH} 7.5)$. Blanks were measured at $240 \mathrm{~nm}$ just before adding $80 \mu \mathrm{L}$ of $\mathrm{H}_{2} \mathrm{O}_{2}(10 \mathrm{mM}$ final) to start the reaction. Catalase activity was determined by measuring the absorbance at $240 \mathrm{~nm}$ and was calculated using a calibration standard curve of increasing amount of catalase between 12.5 and 125 unit $/ \mathrm{ml}$. Catalase activity was expressed as international catalytic units per mg of proteins. Thioredoxin reductase (TrxR) activity in plasma and liver tissues was determined by employing a commercially available assay kit (Abcam [ab83463], Cambridge MA), according to the manufacturer's protocol.

Proteasome activity measurements i.e. chymotrypsin-like, trypsinlike, and caspase-like activities of the proteasome were assayed using fluorogenic peptides (Sigma-Aldrich, St Louis): Suc-Leu-Leu-Val-Tyr7-amido-4-methylcoumarin (LLVYMCA at $25 \mathrm{mM}$ ), N-t-Boc-Leu-SerThr-Arg-7-amido-4-methylcoumarin(LSTR-MCA at $40 \mathrm{mM}$ ) and NCbz-Leu-Leu-Glu-bnaphthylamide (LLE-NA at $150 \mathrm{mM}$ ), respectively, as described in a previous study [21].

Citrate synthase activity was assayed in mitochondrial extract according to the method described by Srere [29]. The reaction mixture contained $50 \mathrm{mM}$ Tris buffer (pH 7.5), $0.1 \mathrm{mM}$ EDTA, $0.1 \mathrm{mM}$ acetylCoA, $0.2 \mathrm{mM}$ 5,5'-di-thiobis-(2-nitrobenzoic acid) (DTNB), $0.05 \%$ triton $\mathrm{X}-100$, and the enzyme extract. The reaction was initiated with $0.5 \mathrm{mM}$ oxaloacetate and monitored at $412 \mathrm{~nm}$ for $3 \mathrm{~min}$ at $25^{\circ} \mathrm{C}$. The enzyme activity was calculated using an extinction coefficient of $13,600 \mathrm{M}^{-1} \mathrm{~cm}^{-1}$ at $412 \mathrm{~nm}$. Citrate synthase activity was expressed as nmol of reduced DTNB per minute and per mg protein.

\subsection{Mitochondrial extraction and respiratory rate measurement}

After mice anesthesia and euthanasia, livers were quickly excised, weighted, rinsed and homogenized with a Potter into $30 \mathrm{ml}$ of isolation medium (250 mM sucrose, $20 \mathrm{mM}$ Tris- $\mathrm{HCl}$ and $5 \mathrm{mM}$ ethylene glycol tetraacetic acid (EGTA), pH 7.4). Nuclei and cell debris were removed after centrifugation at $800 \mathrm{~g}$ for $10 \mathrm{~min}$. Mitochondria were isolated from the supernatant by spinning twice at $8000 \mathrm{~g}$ for $10 \mathrm{~min}$. The mitochondrial pellet was resuspended in $1 \mathrm{ml}$ of isolation buffer and kept on ice. Mitochondrial protein concentration was measured using BCA reagent.

For oxygen consumption measurement, mitochondria (final concentration about $0.5 \mathrm{mg} / \mathrm{mL}$ ) were incubated in an oxygraph cuvette with a Clark electrode. All experiments were done at $37^{\circ} \mathrm{C}$ in the

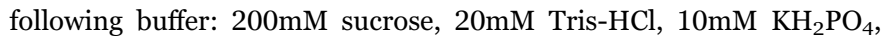
$0.1 \%$ free fatty acid-HSA, $\mathrm{pH} 7.4$ at $37^{\circ} \mathrm{C}$. The nonphosphorylating respiration (state 4) was initiated by addition of $5 \mathrm{mM}$ succinate and glutamate substrates. After signal stabilization, ADP (0.5 mM) was added in order to measure phosphorylating respiration (State 3). Finally, a protonophoric uncoupler, dinitrophenol (DNP, $100 \mu \mathrm{M}$ ) was injected to determine uncoupled mitochondrial respiration.

\subsection{Triglyceride assay in liver}

The measurement of triglyceride levels in tissues was performed with a commercial triglyceride quantification kit (Biovision) after a lipid extraction from liver tissues with chloroform/ triton X100, 1\% (v/ v) solution.

\subsection{Immunohistochemistry}

\subsubsection{Determination of liver RAGE expression}

RAGE immunohistochemistry was performed on paraffin liver sections $(7 \mu \mathrm{m})$ of $\mathrm{db} / \mathrm{db}$ and $\mathrm{db} /+$ mice $(\mathrm{n}=3)$ using the Dako EnVision $^{\mathrm{TM}}+$ Dual Link System-HRP kit according to the manufacturer's instructions (K4065; DAKO, Glostrup, Denmark AS, Denmark) 
Table 1

Clinical, metabolic and oxidative parameters in plasma of diabetic $(\mathrm{db} / \mathrm{db})$, heterozygous $(\mathrm{db} /+)$ and wild type (wt) mice.

\begin{tabular}{|c|c|c|c|}
\hline & Wild type & $\mathbf{d b} /+$ & $d b / d b$ \\
\hline \multicolumn{4}{|c|}{ Clinical and metabolic parameters } \\
\hline $\mathbf{N}$ & 10 & 10 & 10 \\
\hline Body weight (g) & $24.58 \pm 0.63$ & $29.62 \pm 1.25$ & $46.72 \pm 3.26^{* * * *}$ \\
\hline EAT (g) & $0.304 \pm 0.04$ & $0.555 \pm 0.09$ & $2.430 \pm 0.21^{* * * *}$ \\
\hline Fasting glycemia (mg/dl) & $58.28 \pm 6.92$ & $56.57 \pm 13.97$ & $315.14 \pm 66.59^{* * * *}$ \\
\hline Total protein $(\mathrm{g} / \mathrm{l})$ & $38.72 \pm 1.32$ & $41.56 \pm 2.25$ & $48.31 \pm 5.13^{* * * *}$ \\
\hline Albuminemia (g/l) & $27.67 \pm 1.14$ & $29.28 \pm 1.92$ & $31.43 \pm 1.59^{* * * *}$ \\
\hline Insulinemia (pmol/l) & $222.54 \pm 10.70$ & $177.91 \pm 59.53$ & $402.48 \pm 74.05^{* * *}$ \\
\hline HOMA-IR & $4.85 \pm 1.04$ & $4.04 \pm 2.54$ & $21.90 \pm 5.06^{* * * *}$ \\
\hline Fructosamine (mmol/l) & $328.37 \pm 69.66$ & $311.25 \pm 69.55$ & $534.62 \pm 100.37^{* * * *}$ \\
\hline Cholesterol (mmol/l) & $1.96 \pm 0.15$ & $2.04 \pm 0.23$ & $2.64 \pm 0.51^{* * * *}$ \\
\hline HDL (mmol/l) & $1.52 \pm 0.25$ & $1.70 \pm 0.29$ & $2.19 \pm 0.41^{* * *}$ \\
\hline LDL (mmol/l) & $0.19 \pm 0.07$ & $0.19 \pm 0.08$ & $0.26 \pm 0.07$ \\
\hline Triglycerides (mmol/l) & $1.50 \pm 0.41$ & $1.27 \pm 0.27$ & $2.31 \pm 0.65^{* * *}$ \\
\hline \multicolumn{4}{|c|}{ Oxidative parameters } \\
\hline $\mathbf{N}$ & 3 & 5 & 6 \\
\hline Thiol (nmol/g of protein) & $1.05 \pm 0.51$ & $1.06 \pm 0.32$ & $0.98 \pm 0.14$ \\
\hline GSH:GSSG ratio & - & $3.31 \pm 1.95$ & $1.48 \pm 0.74$ \\
\hline Carbonyl (nmol/nmol of protein) & $0.81 \pm 0.04$ & $0.75 \pm 0.18$ & $0.99 \pm 0.09$ \\
\hline $\mathrm{HT}_{\mathbf{5 0}}(\mathrm{min})$ & $356.37 \pm 23.56$ & $297.17 \pm 31.80$ & $270.98 \pm 16.68$ \\
\hline Fluorescent AGE (AU/ $\mu$ g of protein) & $240.91 \pm 53.25$ & $217.80 \pm 39.75$ & $310.34 \pm 28.72^{* * *}$ \\
\hline AOPP (nmol/mg protein) & $1.18 \pm 0.30$ & $1.33 \pm 0.25$ & $1.91 \pm 0.48$ \\
\hline$A C B$ index (AU) & - & $0.48 \pm 0.21$ & $0.78 \pm 0.12$ \\
\hline Catalase activity (U/mg of protein) & $0.85 \pm 0.18$ & $0.67 \pm 0.29$ & $0.92 \pm 0.56$ \\
\hline Total SOD activity (U/mg of protein) & $8.37 \pm 1.13$ & $8.35 \pm 0.81$ & $10.57 \pm 1.28^{* *}$ \\
\hline GPX activity (U/mg of protein) & $59.28 \pm 0.37$ & $46.00 \pm 5.11$ & $56.54 \pm 5.11^{* * *}$ \\
\hline TrxR activity (U/ml/mg of protein) & - & $3.67 \pm 2.14$ & $1.39 \pm 1.13^{*}$ \\
\hline
\end{tabular}

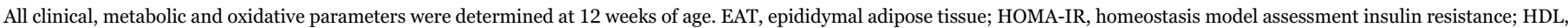

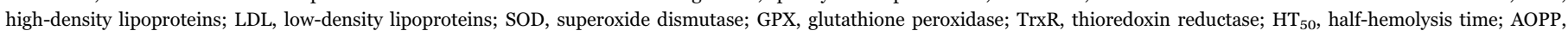
advanced oxidation end-products. Values are shown as mean \pm SD $(n=10)$.

${ }^{*} \mathrm{P}<0.05$.

*** $\mathrm{P}<0.01$.

**** $\mathrm{P}<0.001$ indicate a significant difference $v s . \mathrm{db} /+$ group.

with minor modifications. Briefly, sections were deparaffinized, rehydrated and an antigen retrieval was performed in sodium citrate buffer $(\mathrm{pH} 6 ; 0.01 \mathrm{M})$ for $2 \mathrm{~min}$ in a microwave $(700 \mathrm{~W})$. Sections were incubated overnight at room temperature with the RAGE antibody (1/ 100; Abbiotec; Ref: 251890) in PBS-Triton (0.05\%) containing 5\% BSA. The next day, after incubation with the labeled polymer HRP (K4065; DAKO) and staining with the substrate chromogen 3,3'diaminobenzidine tetrahydrochloride (DAB) (K4065; DAKO), sections were counterstained with DAPI and slides mounted with the antifading medium Vectashield (Vector Laboratories, Burlingame, CA).

\subsubsection{Determination of liver reactive oxygen species formation using dihydroethidium}

Unfixed livers were sampled and frozen at $-80{ }^{\circ} \mathrm{C}$ before being embedded in OCT (Tissue Tek, Sakura, Torrance, CA, USA) and cut at a $10 \mu \mathrm{m}$ thickness using a cryotome (Thermo Scientific, Shandon ${ }^{\mathrm{TM}}$ cryotome FE). Slides were defrosted for $1 \mathrm{~h}$ at room temperature in a humidified chamber. Sections were next incubated with $2 \mu \mathrm{M}$ DHE (dissolved in PBS; Sigma-Aldrich, Ref: D7008) in a light-protected humidified chamber at $37^{\circ} \mathrm{C}$ for 30 min before being washed twice in PBS and mounted with the anti-fading medium Vectashield (Vector Laboratories, Burlingame, CA). For double staining with VE-cadherin, the sections were saturated for $15 \mathrm{~min}$ in PBS containing 5\% BSA to avoid non-specific binding sections. The sections were then incubated overnight at $4^{\circ}$ with rabbit polyclonal anti-VE-cadherin $(1 / 200$; Abcam; Ref: ab33168) in 1\% BSA-PBS. The next day sections were washed several times in PBS and incubated for $90 \mathrm{~min}$ at room temperature with $4^{\prime}, 6^{\prime}$-diamidino-2-phenylindole (DAPI) for cell nuclei counterstaining and with the donkey anti-rabbit Alexa fluor 488 secondary antibody (1:200; Ref: A21206; Life Technologies). Elastic lamina labeling was obtained by auto-fluorescence after excitation at
$488 \mathrm{~nm}$ as described previously [30].

\subsection{Western-blot and dot-blot analysis}

Western-blots were performed in triplicate for catalase (Everest biotech, Ref: EB07282; 1 :500 dilution), Mn-SOD (Sigma, Ref: SAB2501676; $1: 1000$ dilution), glutathione peroxidase (Pierce, Ref: PA5-30593; 1 :1000 dilution), RAGE (Abbiotec, Ref: 251890; 1 :750 dilution), iNOS (Cell signaling, Ref: 2977; $1: 1000$ dilution), carbonyl (anti-DNPH, Sigma, Ref: D8406; 1 :400 dilution), PGC-1a (Sigma, Ref: AV40129; 1 :1000 dilution), mitochondria (Abcam, Ref: ab3298; 1 :1000 dilution), 4-HNE (Abcam, Ref: ab46545; $1: 1000$ dilution) and GAPDH (Santa Cruz Biotechnologies, Ref: SC25778; 1 :500 dilution). Proteins (around $30 \mu \mathrm{g}$ ) were separated by $10 \%$ SDS-PAGE in reducing conditions and transferred to a nitrocellulose membrane $0.45 \mu \mathrm{m}$ (BioRad, USA). For Western-blot carbonyl determination, proteins $(10 \mu \mathrm{g})$ were preliminary derivatized with10 $\mathrm{mM}$ 2,4-DNPH in $2 \mathrm{M} \mathrm{HCl}$ for $15 \mathrm{~min}$ at room temperature and then neutralized before electrophoretic separation. For 4-HNE Dot-blots, each sample was spotted onto a dry nitrocellulose membrane. The membrane was placed on a 96-well plate. $\mathrm{T}$ provides a guide for spotting sample, a grid from pipette tip rack was used. The membrane was air-dried for $15 \mathrm{~min}$ and was washed twice in acetic acid for $2 \mathrm{~min}$.

Membrane were firstly blocked with PBS/Tween $200.1 \%(\mathrm{v} / \mathrm{v}) /$ milk $5 \%$ for $3 \mathrm{~h}$ at room temperature and then sequentially probed with an appropriate primary antibody for $3 \mathrm{~h}$ (1:1000 dilution) followed by secondary antibody incubation for at least $1 \mathrm{~h}$ (anti-rabbit or antimouse HRP-linked antibodies at 1:2000 dilution). Between each step, membranes were washed three times with PBS/Tween 20 0.1\% (v/v). Detection was performed using the enhanced chemiluminescence (ECL) reagent. Signal quantifications from images were determined 
using the freeware ImageJ (version 1.32j), available from the internet website: http://rsb.info.nih.gov/ij/.

\subsection{Statistical analysis}

Data are expressed as mean \pm standard deviation (SD) from a minimum of three independent experiments. Statistical significances were determined using one-way ANOVA (followed by the Student's $t$ test) for multiple comparisons; a p value of less than 0.05 was required for significance.

\section{Results}

\subsection{Clinical and metabolic parameters in $d b / d b$ mice}

As expected and starting from 5 weeks of age, the weight gain increased to a greater extent in the $\mathrm{db} / \mathrm{db}$ group compared to $\mathrm{db} /+$ and WT groups (Fig. S1A supplementary data). This progressive weight gain led to obesity in $\mathrm{db} / \mathrm{db}$ mice, displaying an average body mass almost twice higher than control littermates by week 12 . The onset of obesity was associated with a marked increase in fasting glycemia levels starting from week 6 (by about $70.3 \% \pm 18.3$ ) whereas it remained unchanged in $\mathrm{db} /+$ and WT groups (Fig. S1B). The determination of different metabolic parameters in the plasma after 12 weeks (Table 1) indicated that the fasting glycemia $(\mathrm{mg} / \mathrm{dL})$ remained significantly higher in $\mathrm{db} / \mathrm{db}$ mice $(315.1 \pm 66.6)$ compared to $\mathrm{db} /+$ littermates $(56.6 \pm 13.9)(\mathrm{p}<0.001)$.

Diabetic mice also displayed a significant increase in the mass of epididymal fat pads vs. controls $(>300 \%, \mathrm{p}<0.001)$ which further confirmed a severe obesity phenotype. Hyperglycemia was associated with a significant increase in fructosamine $(+71.8 \%)$ and protein levels $(+16.2 \%)$ including albuminemia (+7.4\%). Although LDL-cholesterol did not differ significantly between both groups $(\mathrm{db} /+$ and $\mathrm{db} / \mathrm{db})$, total cholesterol $(+29.4 \%)$, HDL-cholesterol $(+28.2 \%)$ and triglycerides $(+81.8 \%)$ levels were significantly higher in diabetic mice. In addition, homeostasis model assessment insulin resistance (HOMA-IR) and serum insulin levels were also significantly increased in the $\mathrm{db} / \mathrm{db}$ group $(\mathrm{p}<0.001)$. The increased fluorescent AGE $(+42.5 \%)$ and carbonyl $(+32.0 \%)$ levels in the $\mathrm{db} / \mathrm{db}$ group associated with a lower GSH: GSSG ratio, reflects a general impairment of redox regulation in this group. This is in accordance with the reduced free radical defense capacity of plasma collected from diabetic mice, characterized by a lower HT value (-31.5\%) compared to the wild type group. The main antioxidant enzyme activities of plasma were measured and revealed a significant upregulation in the diabetic group, i.e. an increase in SOD $(+26.6 \%)$ and glutathione peroxidase $(+22.9 \%)$. By contrast, TrxR activity $(-62.1 \%)$ was attenuated compared to the $\mathrm{db} /+$ mice group. The increase of $\mathrm{ACB}$ index in $\mathrm{db} / \mathrm{db}$ mice, reflecting the alteration of albumin capacity to bind cobalt ion $\left(\mathrm{Co}^{2+}\right)$, was in line with the disturbance of plasma redox homeostasis observed earlier.

As most of measured biochemical parameters were identical between $\mathrm{WT}$ and $\mathrm{db} /+$ groups, our study subsequently focused on the $\mathrm{db} /+v$ s. $\mathrm{db} / \mathrm{db}$ groups.

\subsection{Characterization of oxidative and lipid parameters in diabetic mouse liver}

Different oxidative and lipid parameters were determined in the liver of 12-week diabetic $(\mathrm{db} / \mathrm{db}, \mathrm{n}=8)$ and non-diabetic mice $(\mathrm{db} /+$, $\mathrm{n}=8$ ) (Fig. 1). The altered redox status in plasma of $\mathrm{db} / \mathrm{db}$ mice was also observed in the liver as shown by increased carbonyl $(+23.4 \%)$ (Fig. 1A) and reduced free thiol levels (-16.4\%) (Fig. 1B) compared to non-diabetic mice associated with a significant GSH: GSSG ratio alteration (Fig. 1C). Diabetes also induced steatosis as demonstrated by the robust increase in triglyceride levels in the $\mathrm{db} / \mathrm{db}$ group $v s$. controls (+186.9\%) (Fig. 1D). The lipid accumulation was confirmed by
Oil-Red-O staining, showing numerous lipid droplets in liver tissues from diabetic mice (Fig. 1E).

\subsection{Incidence of diabetes in tissue oxidative markers expression}

The expression of oxidative and inflammatory modulators was next investigated at the genomic and proteomic levels. Here, we found lower hepatic gene expression levels of RAGE as well as an inflammation marker (Il-6), while an oxidation biomarker (iNOS) was upregulated (Fig. 2A-C). Surprisingly, the oxidative environment generated by diabetes did not induce an increase in the pro-inflammatory cytokine IL-6, while RAGE expression was significantly reduced with diabetes. However, iNOS gene expression displayed an upward trend although it did not reach the statistical significance ( $\mathrm{p}=0.06 \mathrm{vs}$. control).

We found similar patterns at the protein level (Fig. 2D and E) for iNOS expression which was significantly higher in $\mathrm{db} / \mathrm{db}$ mouse livers, associated with an upregulation of protein carbonylation. Unlike the gene expression data, RAGE protein levels were significantly higher in diabetic liver tissues compared to controls. However, no significant increase in 4-HNE lipid peroxidation by-product was found for diabetic mice livers. Enhanced RAGE protein levels may arise from an enhanced translation of the mRNA and/or a reduced degradation of the RAGE protein. The latter is consistent with reduced proteosomal activities observed in livers of diabetic mice (Fig. 4K).

\subsection{Upregulation of RAGE expression and ROS production in $d b / d b$ liver}

Since our previous data revealed contradictory results for RAGE and iNOS (gene $v$ s. protein expression), we next performed RAGE immunohistochemistry analysis on liver sections of $d b /+$ and $d b / d b$ mice (Fig. 3). Interestingly, RAGE-positive hepatocytes were mainly localized in areas around blood vessels and we consistently detected larger RAGE-positive areas in liver sections prepared from $\mathrm{db} / \mathrm{db}$ mice $(n=3)$ compared to heterozygous littermates $(n=3)$ (Fig. $3 \mathrm{C}$ and $\mathrm{D}$, arrows). The intensity of RAGE staining was also stronger in $\mathrm{db} / \mathrm{db}$ hepatocytes, notably in cells surrounding blood vessels (Fig. 3E and F, arrows). Diabetic mice thus exhibit larger RAGE-positive areas as well as stronger RAGE staining intensity compared to control mice.

The oxidative fluorescent dye dihydroethidium (DHE) was used as a marker for intracellular ROS production (Fig. 3). Incubation with DHE showed weak staining of few cell nuclei localized around blood vessels on $\mathrm{db} /+$ liver sections (Fig. $3 \mathrm{~K}$ and $\mathrm{M}$, arrowheads). In stark contrast, $\mathrm{db} / \mathrm{db}$ liver sections exhibited a robust increase in DHE-positive cells in the parenchyma and around blood vessels (Fig. 3L and N, arrowheads). Furthermore, cells surrounding blood vessels also displayed a stronger DHE staining intensity compared to parenchymal cells, suggesting that ROS production is higher in the vascularized areas (Fig. $3 \mathrm{~L}$ and N asterisks). Vascular endothelial-cadherin immunohistochemistry was performed on liver sections of $\mathrm{db} / \mathrm{db}$ mice after DHE staining (Fig. 3OS, arrows). In addition, lamina elastic of blood vessels was also visualized by auto-fluorescence and DAPI counterstaining highlights the presence of elongated and flat cell nuclei (Fig. 3QRUV, arrowheads) in the lumen of blood vessels. Such cell nuclei are typical of endothelial cells. These data clearly show that DHE positive cells of $\mathrm{db} / \mathrm{db}$ liver sections concern blood vessels and surrounding parenchyma.

Taken together, these data show that ROS production and RAGE signaling are strongly increased in livers of $\mathrm{db} / \mathrm{db}$ mice and they are both localized around the blood vessels.

\subsection{Diabetes impaired main antioxidant and proteasome activities in livers of $d b / d b$ mice}

The expression of a range of antioxidant enzymes (catalase, SOD and glutathione peroxidase) was investigated at the genomic, proteo- 

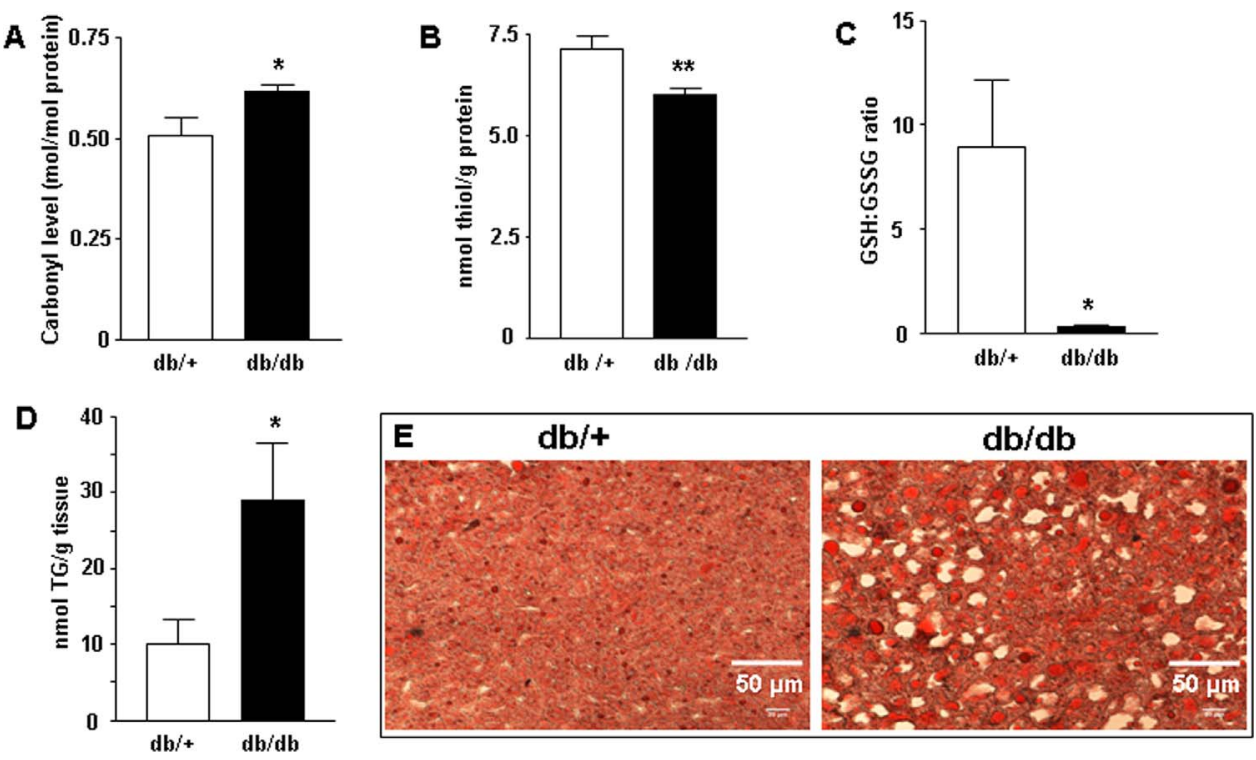

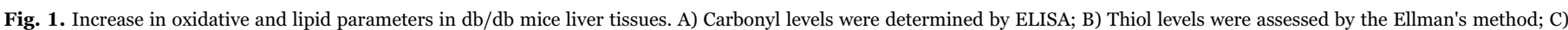

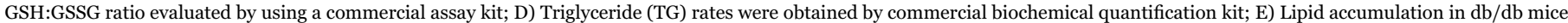
livers assessed by red oil staining of liver tissues. All data are expressed as mean $\pm \mathrm{SD}(\mathrm{n}=6)$. ${ }^{* * *} \mathrm{P}<0.001$ and ${ }^{*} \mathrm{P}<0.05$ indicate a significant difference $v$ s. db/+ group.

mic and functional levels. The corresponding gene expression levels of antioxidant enzymes are reported in Fig. 4A-D. Although mRNA levels of $\mathrm{Cu} / \mathrm{Zn}-\mathrm{SOD}(\mathrm{SOD} 1)$ between both groups $(\mathrm{db} /+\mathrm{and} \mathrm{db} / \mathrm{db})$ were not significantly altered, the expression of other antioxidant enzyme genes (catalase, SOD2 and glutathione peroxidase) was significantly higher in diabetic mice $v s$. controls. Mn-SOD and glutathione peroxidase protein levels were significantly higher while the slight increase in catalase protein levels failed to reach statistical significance (Fig. 4E and F).

As previously observed, gene and protein expression levels of antioxidant enzymes do not necessarily reflect their activities. Indeed, except for Mn-SOD and for TrxR, most of the antioxidant activities were significantly decreased in $\mathrm{db} / \mathrm{db}$ livers $v$ s. controls, i.e. for catalase $(-19.5 \%)$, glutathione peroxidase $(-15.7 \%)$ and for $\mathrm{Cu} / \mathrm{Zn}-\mathrm{SOD}$ (-59.8\%) (Fig. 4G-J).

Similarly, we found a significant reduction of all proteolytic activities of the UPS in liver tissues from $\mathrm{db} / \mathrm{db}$ mice (Fig. 4K). Here, a reduction was observed for the chymotrypsin-like activities (LLVY) (-19.3\%), while the impairment was even more marked for trypsin-like (LSTR) (-42.2\%) and caspase-like (LLE) (-46.2\%) activities.

\subsection{Mitochondrial metabolism of liver in diabetes context}

We next investigated whether the upregulation of Mn-SOD expression and enzymatic activity in $\mathrm{db} / \mathrm{db}$ liver were dependent on mitochondrial metabolism activation. To test this hypothesis, hepatic mitochondrial respiration was assessed through the determination of the spontaneous (state 4), ADP-stimulated (state 3) and uncoupled respiration (Fig. 5A). The hepatic mitochondrial oxygen consumption rate in state 4 was markedly decreased $(-32.9 \%)$ in $\mathrm{db} / \mathrm{db}$ mice compared to $\mathrm{db} /+$ controls. By contrast, the respiratory rate in state 3 remained unchanged between groups after addition of ADP. A similar flux through the citrate synthase in state 3 observed between both groups in Fig. 5C (around $70 \mathrm{nmol}$ per minute and per $\mathrm{mg}$ ); this is in accordance with this unchanged respiratory rate.

The decreased mitochondrial oxygen consumption in diabetic mouse livers (state 4) suggests a decrease in the rate of electron transfer along the mitochondrial respiratory chain. In addition, the respiratory control ratio (state 3/state 4) (Fig. 5B) indicating the degree of coupling between respiration and phosphorylation was significantly enhanced in diabetic mice liver (+46.6\%) compared to control.
Moreover, the uncoupled respiratory rate (resulting from the increase of inner mitochondrial membrane permeability for protons) remained unchanged.

We also assessed the levels of mitochondria and PGC1 $1 \alpha$, a transcriptional coactivator that plays a pivotal role in mitochondrial biogenesis and that is strongly involved in oxidative metabolism regulation [31]. Our data demonstrate a significant decrease in PGC1a protein levels and mitochondria content in $\mathrm{db} / \mathrm{db} v \mathrm{~s} . \mathrm{db} /+$ liver (Fig. 5E). If a higher carbonyl level in proteins was observed in plasma and in liver tissue from diabetic mice, carbonylation was shown to be significantly reduced when considering mitochondrial proteins (Fig. 5D).

Together, the in vivo liver data strongly suggest a robust increase in oxidative stress in diabetic mice that is not thwarted due to impaired antioxidant systems. These findings are in line with the alteration of redox status already observed in plasma and for albumin, the major plasma protein (in terms of abundance and redox regulator). In addition, the higher AGE levels are associated with the impairment of the albumin cobalt binding capacity (ACB) index thus supporting our hypothesis (Table 1).

\subsection{Diabetic mice display altered albumin}

Structural and biochemical characterization of mouse albumin (MSA) from control $(\mathrm{db} /+, \mathrm{n}=3)$ and diabetic $(\mathrm{db} / \mathrm{db}, \mathrm{n}=3)$ mice was next evaluated after its isolation from plasma and compared with native (HSA) and in vitro glycated human albumin (AGE) (Fig. 6). As illustrated in Fig. 6A and B, a quenching of maximum tryptophan emission fluorescence at around $340 \mathrm{~nm}$ was observed for $\mathrm{db} / \mathrm{db}$ MSA and AGE $v s$. db/+ albumin and HSA, respectively. This quenching of fluorescence emission reflects the structural changes in the tryptophan (and tyrosine) environment under glycation conditions. Quenching of tryptophan fluorescence may also result in both the destruction of Trp and the formation of new fluorescence active products ( $\mathrm{N}$-formyl kynurenine and kynurenine) [32]. These conformational and chemical changes were moreover correlated with a glycophore fluorescence increase for db/db MSA, reflecting AGE formation (Fig. 6D and E). Whereas analysis by SDS-polyacrylamide gel electrophoresis exhibited an approximately identical molecular weight between HSA and MSA, native electrophoresis condition showed significant differences in migration patterns (Fig. $6 \mathrm{H}$ and $\mathrm{J}$ ). Indeed, we found that under 

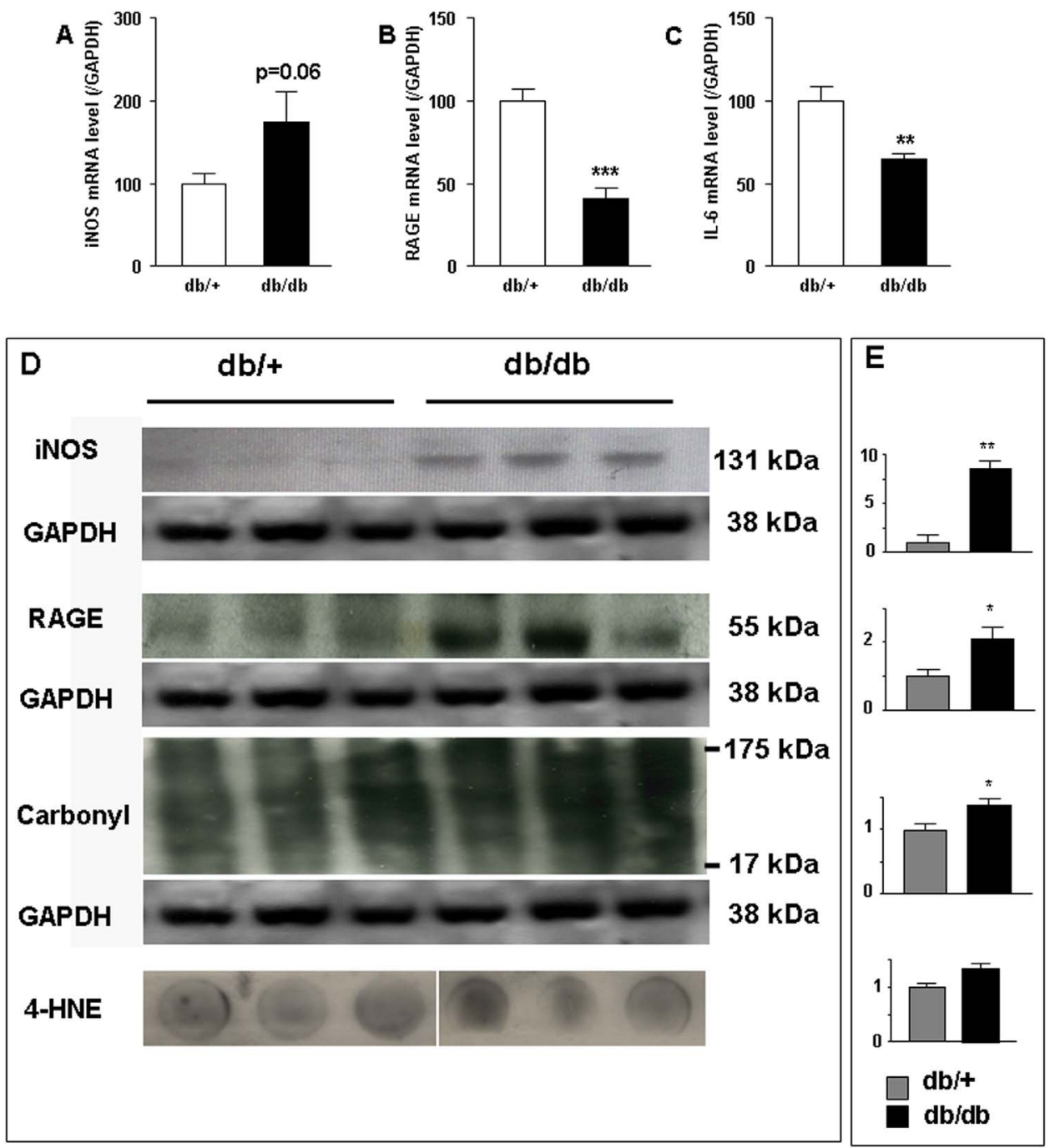

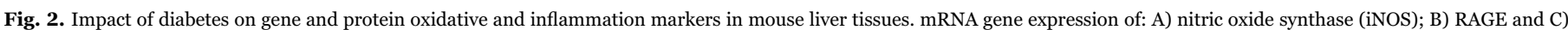

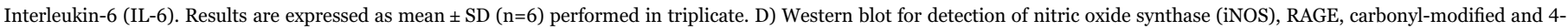

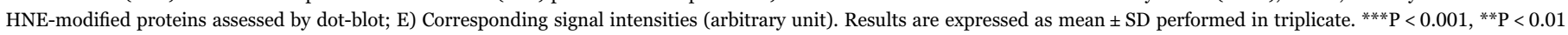
and ${ }^{*} \mathrm{P}<0.05$ indicate a significant difference $v s$. $\mathrm{db} /+$ group.

non-reducing and non-denaturing conditions, the relative electrophoretic migrations for diabetic MSA samples were markedly enhanced compared to $\mathrm{db} /+\mathrm{MSA}$, reflecting a modification of the isoelectric point (pI) of albumin. These differences were also observed between AGE and HSA.

The analysis by MALDI-TOF-MS of albumin samples showed a clear increase of the molecular weight of HSA comparing with HSAAGE $(+1.78 \mathrm{kDa})$ and for MSA from $\mathrm{db} / \mathrm{db}(+0.457 \mathrm{kDa})$ or $\mathrm{db} /$ $+(0.465 \mathrm{kDa})$ mice in comparison with control MSA (Fig. 6I, S2 and S3). This increase was caused by multiple glycation modifications. The biochemical parameters featured in Fig. 6E and $\mathrm{F}$ also confirmed an alteration of $\mathrm{db} / \mathrm{db}$ MSA. Thus $\mathrm{db} / \mathrm{db}$ mouse albumin displayed a significant increase of glycation $(+55.1 \%)$ and AGE $(+33.8 \%)$ levels. Moreover, these results further show that albumin samples purified from $\mathrm{db} / \mathrm{db}$ plasma exhibit biochemical and structural modifications as for the in vitro AGE model derived from HSA.

\subsection{Peptide mapping of both albumin models}

To further characterize these modifications, we analyzed the tryptic peptides of the different types of serum albumins by MALDI-TOF-MS. By comparing with theoretical digestion of unmodified serum albumins, the presence of glycation adducts on glycated albumins was identified after determining the tryptic peptide ions with mass values, which were only present in the glycated samples. Then modifications present in such peptides were characterized by comparing the mass shift with a list of shift mass deviations caused by different glycation adducts (see Supplementary Table S2 and Fig. S4). By using this approach, several modifications were assigned and identified in the glycated samples (Tables 2 and 3). Two restrictions were used on this process to facilitate the assignment of the modifications: only a single modification was allowed within a fragment and the peptide must contain a missed cleavage site (lysine/arginine). In the case of HSA and AGE (Table 2), both molecules showed the same glycation modifications in some specific residues (as K28, K341, K375, K569, K581, K597, R449), whereas other peptides were specifically found on each sample. Some residues were modified in both samples, but with different glycation modifications: K28, K257, K341, K597, R360. The type of modifications were almost the same, but Ne-(5-Hydro-4imidazolon-2-yl)ornithine was only found in HSA, whereas argpyrimidine was only observed in HSA-AGE.

Regarding the MSA samples, although the analysis of the molecular mass did not show a significant difference between MSA from $\mathrm{db} /+$ and $\mathrm{db} / \mathrm{db}$ mice, this allowed for a better comparison of both molecules by peptide mapping, since such samples seem to have a similar number of modifications. More modified peptides fitting the criteria of our 

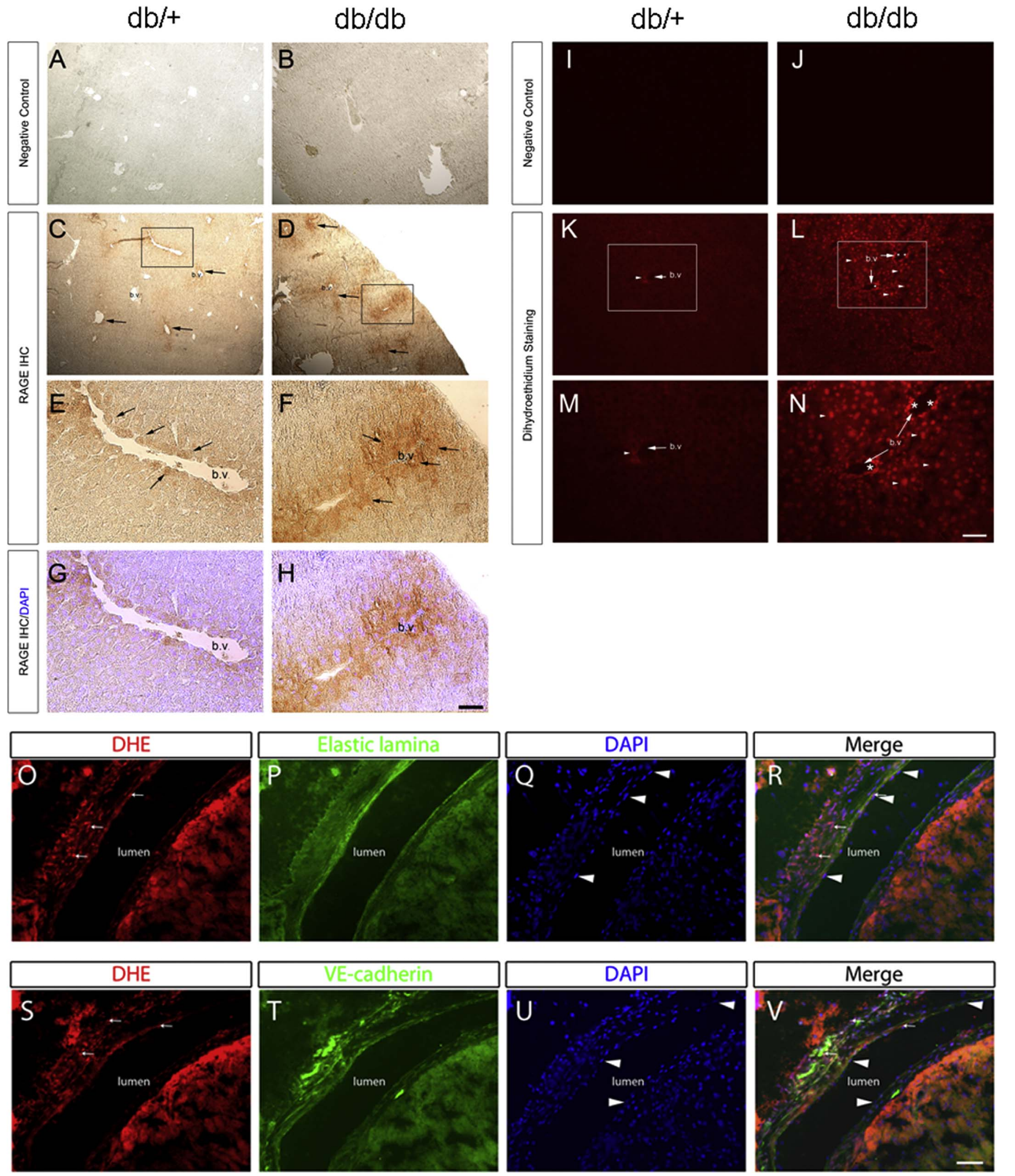

Fig. 3. RAGE expression and ROS production are up-regulated in the liver of db/db mice.RAGE expression: $\mathrm{A}$ and B: Negative control showing the background in the liver of Db/+ and $\mathrm{db} / \mathrm{db}$ mice when the first antibody is omitted. C and D: RAGE immunostaining in $\mathrm{db} /+$ and diabetic mice $(\mathrm{n}=3)$. RAGE labeling is detected in larger areas in $\mathrm{db} / \mathrm{db}$ mice compared to controls (see arrows). RAGE staining is mainly localized around blood vessels (b.v.). E and F: higher magnification views of the squared areas in C and D, respectively. RAGE staining is stronger and more widely distributed in the liver of $\mathrm{db} / \mathrm{db}$ vs db/+ mice. G and H: Merge pictures of E and F with DAPI. Bars: $220 \mu \mathrm{m}(\mathrm{A}, \mathrm{B}, \mathrm{C}$ and D); $55 \mu \mathrm{m}$ (E, F, G and H). ROS production: I and J: Negative control showing the liver auto-fluorescence of $\mathrm{db} /+$ and $\mathrm{db} / \mathrm{db}$ mice when DHE dye is omitted. $\mathrm{K}$ and L: ROS staining in heterozygous and diabetic mice $(\mathrm{n}=3)$. A very weak ROS production is detected around the blood vessels (b.v.) of control mice as shown by the arrowhead (K). ROS production is markedly increased in the whole liver of $\mathrm{db} / \mathrm{db}$ mice relative to $\mathrm{db} /+$ mice (see arrowheads in $\mathrm{L}$ ). In diabetic mice, cells surrounding the blood vessels also exhibit a more intense ROS staining (see asterisks in $\mathrm{L}$ ). $\mathrm{M}$ and $\mathrm{N}$ : higher magnification views of the squared areas in K and L respectively. Bars: $110 \mu \mathrm{m}(\mathrm{I}, \mathrm{J}, \mathrm{K}$ and L); $55 \mu \mathrm{m}$ (M and N). O-V: DHE staining (red, arrows) is observed around blood vessels as shown by elastic lamina and VE-cadherin staining (green). Arrowheads show the presence of elongated and flat nuclei of endothelial cells in the lumen of the blood vessel. Bars: $42 \mu \mathrm{m}$. (For interpretation of the references to color in this figure legend, the reader is referred to the web version of this article). 

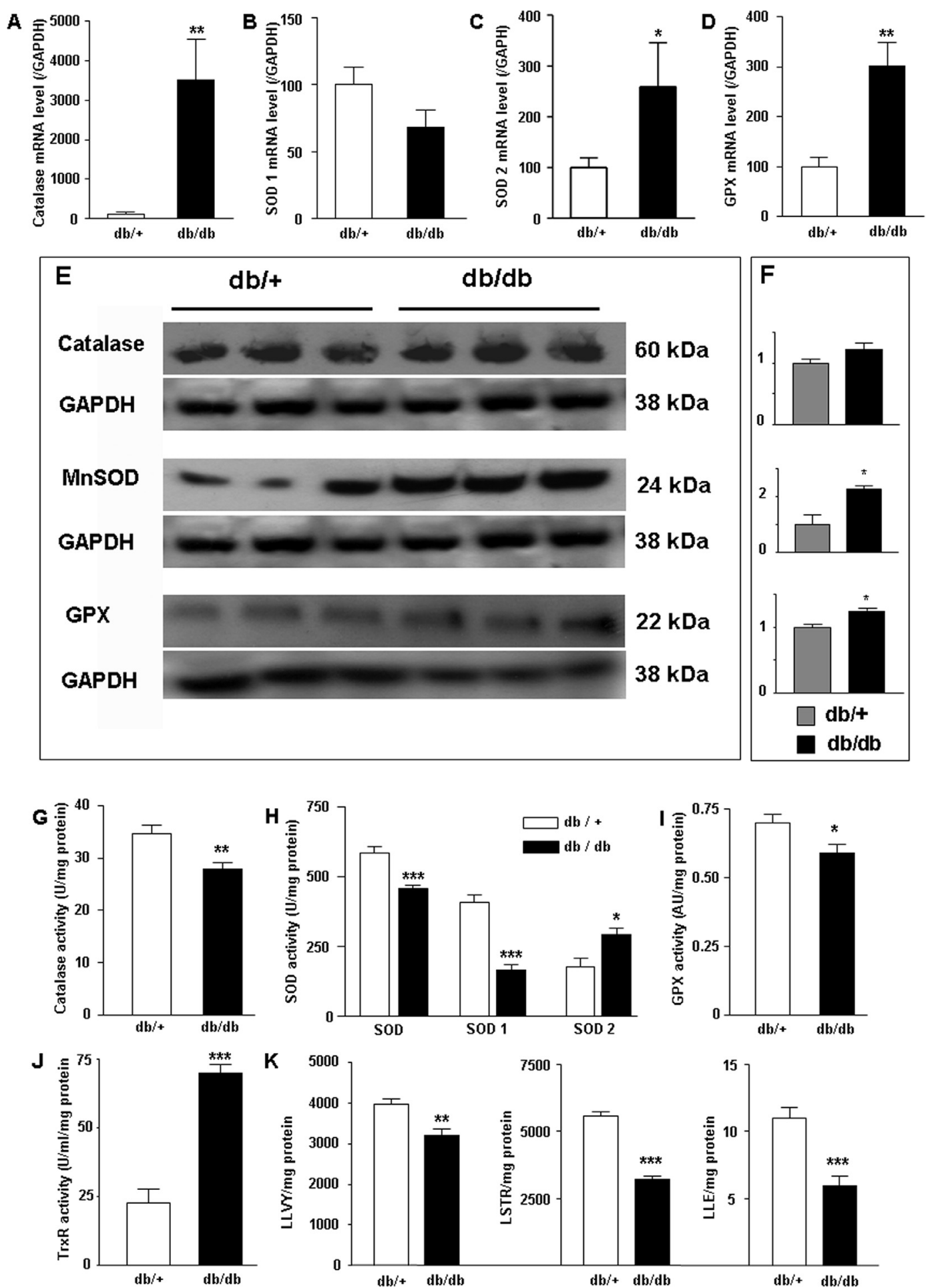

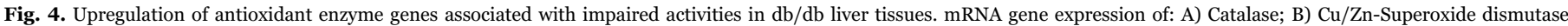

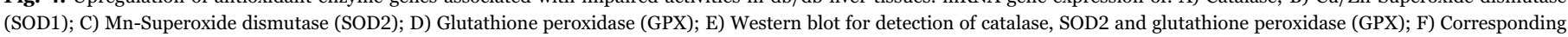

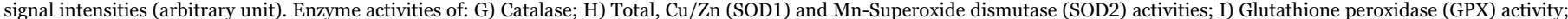

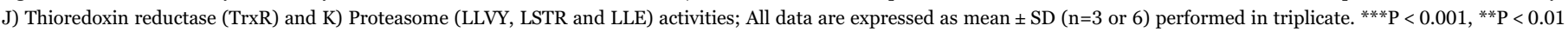
and ${ }^{*} \mathrm{P}<0.05$ indicate a significant difference $v s$. db/+ group.

analysis were found in $\mathrm{db} / \mathrm{db}$ than in $\mathrm{db} /+$ (cf. Table 3 ) samples. All the types of modifications found were equal in both samples, except for imidazolone B that only appeared in $\mathrm{db} /+$ albumin. Interestingly, MSA from $\mathrm{db} / \mathrm{db}$ mice showed some residues with more than one type of glycation modifications (K223, K347, K376, K584), suggesting a relatively higher level of glycation for this molecule.

\subsection{In vitro impact of albumin-AGE on liver cellular model}

HepG2 cell line (cultured human hepatocytes), was used as a model to monitor the biological effects of AGE derived from human albumin. Cell viability, intracellular oxidative stress and antioxidant enzyme expression and activities were the main biological parameters assessed in HepG2 cells cultured in the presence of HSA or HSA-AGE $(50 \mu \mathrm{M})$. 

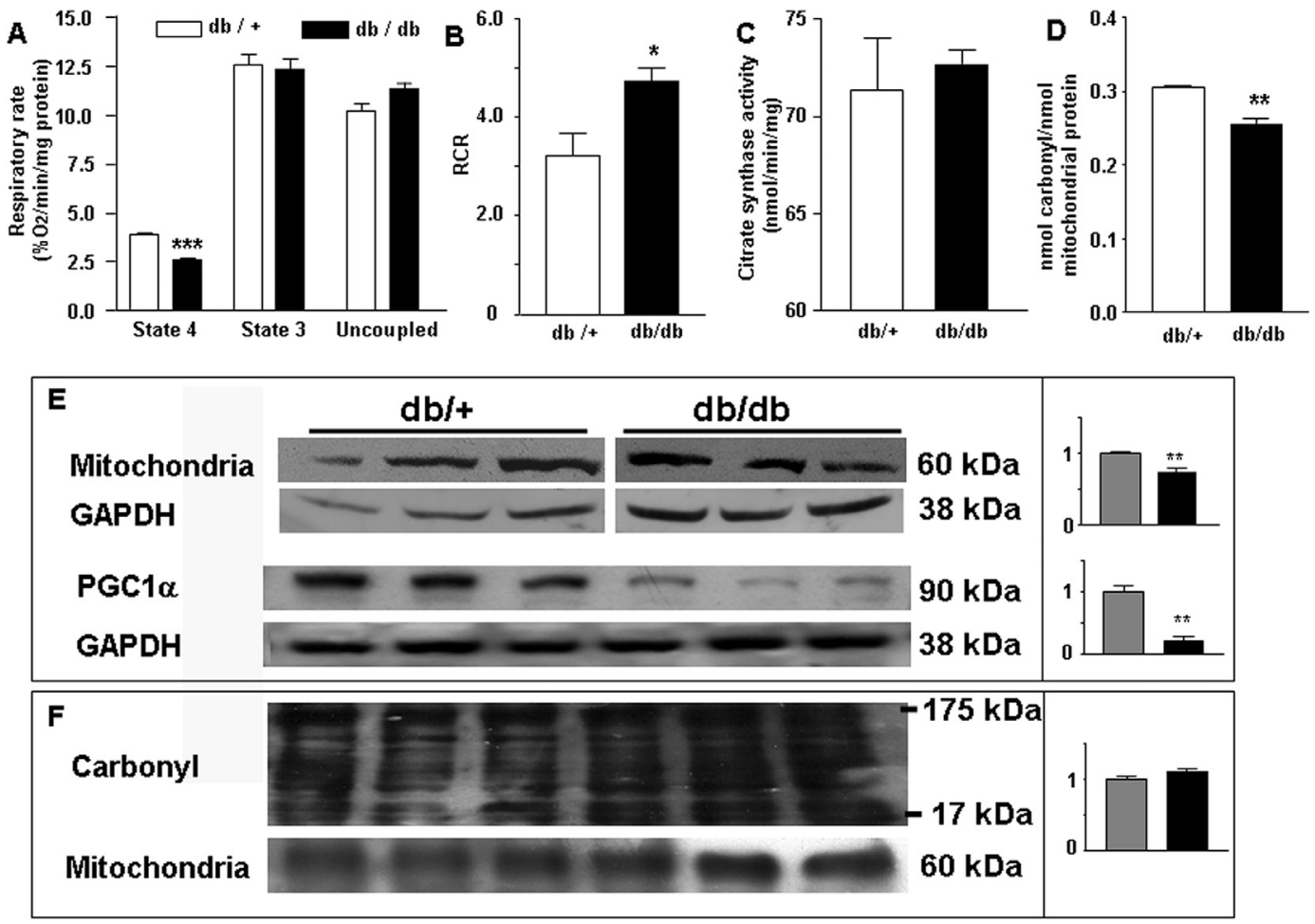

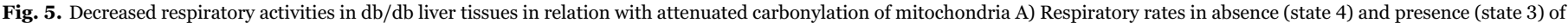

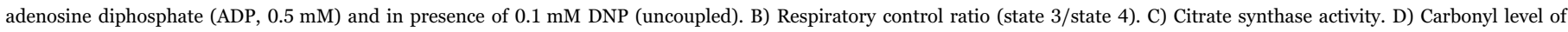

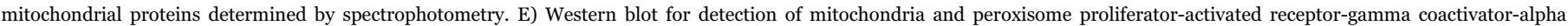

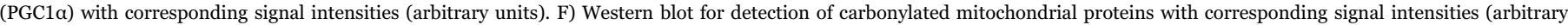
units). All data are expressed as mean $\pm \mathrm{SD}(\mathrm{n}=3$ or 6$)$ performed in triplicate. ${ }^{* * *} \mathrm{P}<0.001,{ }^{* *} \mathrm{P}<0.01$ and ${ }^{*} \mathrm{P}<0.05$ indicate a significant difference $v$ s. db/ + group.

This albumin concentration was chosen for the incubations as it is more than ten times less than the physiological concentration (about $0.7 \mathrm{mM}$ ) and to be compatible with circulating AGEs concentrations typically encountered in pathological situations [21]. Under our experimental conditions, the MTT viability indicated that AGE did not exert any cytotoxic effect on HepG2 cells (Fig. 7A). However, AGE exposure induced intracellular oxidative stress as detected by both DHE and DCF probes as shown in Fig. $7 \mathrm{~B}$ and $\mathrm{C}$, respectively. Significant enhancements in ROS production were observed with cells treated for $1 \mathrm{~h}, 2 \mathrm{~h}, 12 \mathrm{~h}, 24 \mathrm{~h}$ and $48 \mathrm{~h}$ in the presence of HSA-AGE $v s$. cells treated with native albumin. This result shows that enhanced ROS production may be attributed to not only short term but also to long term effects of HSA-AGE (Fig. 7C). AGE-induced oxidative stress was associated with an overall increase in gene expression levels for most antioxidant enzymes and AGE receptors (Fig. 8). Indeed, both specific receptors for AGE (RAGE and CD36) were found to be upregulated in HepG2 cells treated with AGE, with $112.6 \%$ and 59.9\%, increases, respectively ( $v s$. HSA, p < 0.05). Although, enhanced catalase mRNA expression failed to reach statistical significance $(\mathrm{p}=0.08)$, SOD1 and glutathione peroxidase mRNA levels were markedly increased in HepG2 cells treated with HSA-AGE. The significant increase in catalase activity $(+33.7 \%$, vs. HSA, $\mathrm{p}<0.05)$ was in accordance with the upregulation of catalase gene upon AGE treatment. On the contrary, SOD activity did not reflect the increase in its gene expression. HSAAGE exposure also induced a stimulating effect on trypsin-like (LSTR) activity of the proteasome $(+304.3 \%$, vs. HSA, $\mathrm{p}<0.05)$ whereas a nonsignificant increase was noted for LLVY activity (Fig. 8H).

\section{Discussion}

Our present study demonstrates oxidative damages in the liver of diabetic mice and highlights the potential role of glycated albumin in mediating such deleterious alterations. High concentrations of circu- lating AGEs derived from albumin represent a typical "blood fingerprint" in diabetes mellitus [4]. Circulating glycated proteins can contribute to tissue alterations and intracellular metabolic disturbances with subsequent pathological consequences. The interaction of AGEs with RAGE in many tissue/cell types can trigger intracellular oxidative stress resulting in the activation of a cascade of intracellular signals involving pathways such as p21 $1^{\text {ras }}$, mitogen activated protein kinase (MAP-kinase) or protein kinase C (PKC) [7,33]. The interaction between glycated proteins and tissues/cells is also known to modulate signal transduction through ROS formation [7,8]. Although extensive research work demonstrated oxidative stress-mediated injury in the liver during diabetes, few studies have focused on the pathogenic role of glycated albumin in this organ. Thus, the current study aimed at highlighting the potential link between hepatic oxidative damage and glycoxidative alterations of plasma albumin in diabetic mice.

In our study, the diabetic phenotype was characterized by an extensive triglyceride accumulation both in plasma and in liver cells, reflecting hepatic steatosis. The results presented here are in accordance with previous studies describing increased hepatic oxidative stress in an experimental mouse model of diabetes mellitus $[34,35]$. These studies showed an impairment of antioxidant enzymic activities associated with liver oxidative alterations. The oxidative damage stimulates the expression of antioxidant and repair enzymes to counter the overall redox status imbalance. Indeed, most oxidative parameters in plasma collected from diabetic mice are increased and associated with an activation of the main antioxidant enzymes (catalase, SOD and glutathione peroxidase). In diabetic mouse liver, hyperglycemia induced the upregulation of the main oxidative stress markers and antioxidant enzymes but impaired their corresponding activities which may facilitate ROS-mediated damage of tissues/cells. The proteasome represents the main constituent of the proteolytic pathway for the degradation of oxidized proteins [36]. However in the diabetic context, all the main proteolytic activities of the proteasome system were 
A

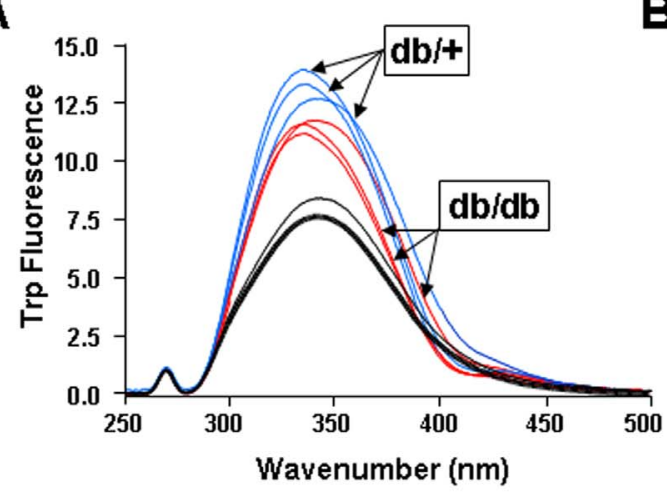

D

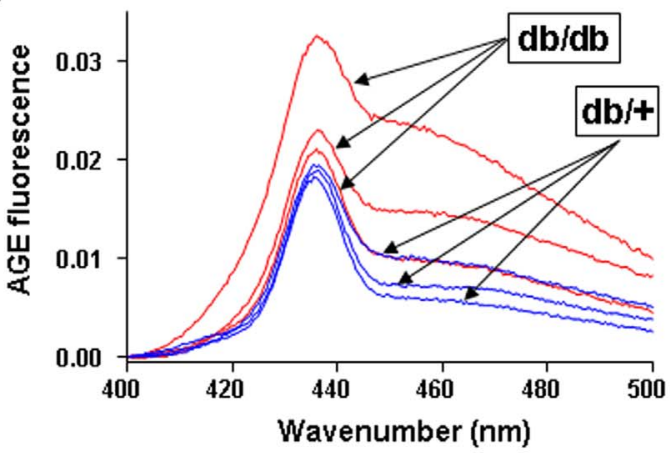

B

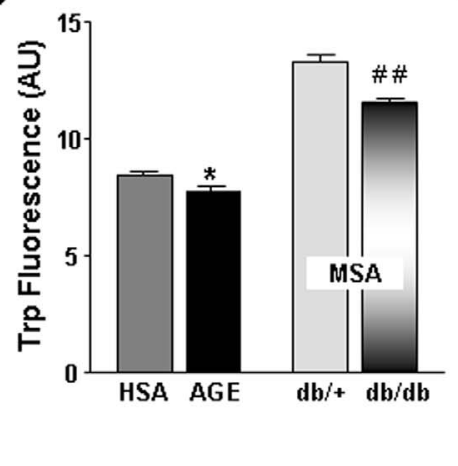

C

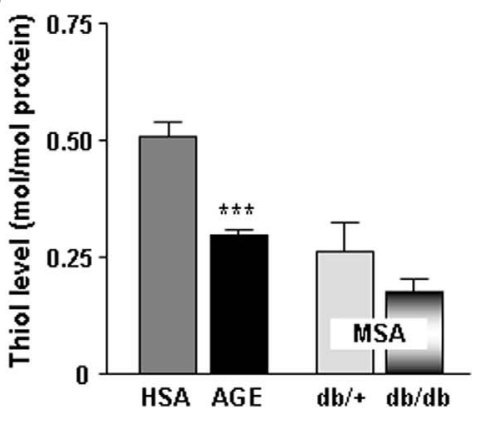

$\mathbf{F}$
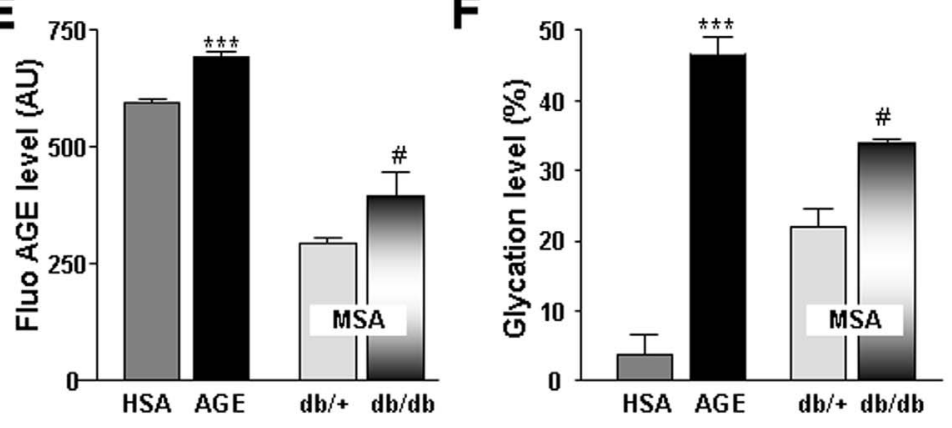

G

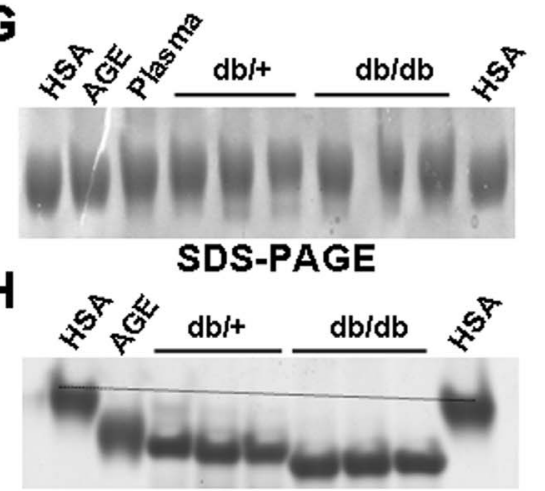

NATIVE-PAGE
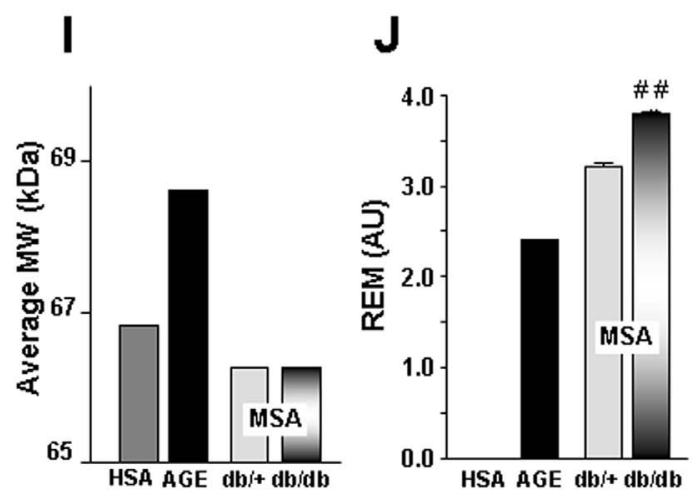

$\mathbf{K}$

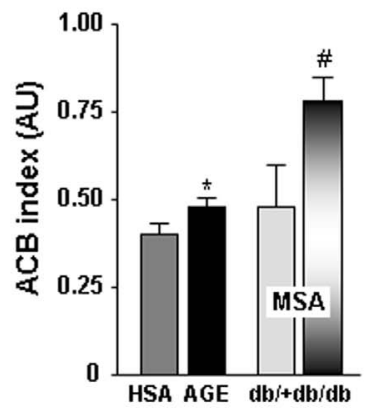

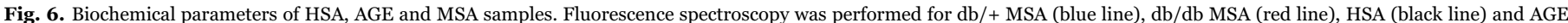

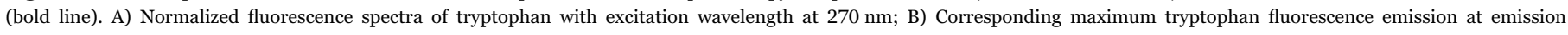

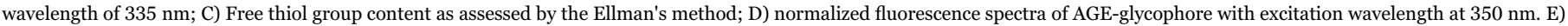

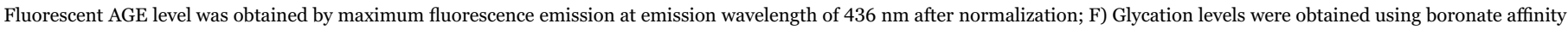

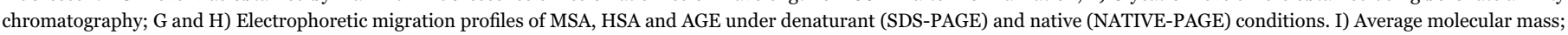

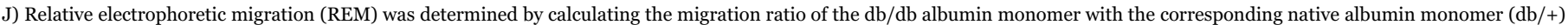

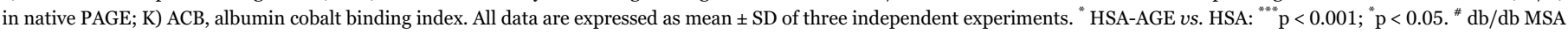
vs. $\mathrm{db} /+$ MSA: ${ }^{\# \# \#} \mathrm{p}<0.001 ;{ }^{\# \#} \mathrm{p}<0.01 ;{ }^{*} \mathrm{p}<0.05$. (For interpretation of the references to color in this figure legend, the reader is referred to the web version of this article).

markedly impaired in the liver. These findings support the hypothesis that oxidative stress in the liver can irreversibly damage major proteins that include antioxidant and proteasome enzymes. This potential loss of protein function may lead to liver dysfunction. The partial or complete inactivation of antioxidant enzymes may also be caused by glycation-mediated damage of some target enzymes e.g. catalase [37] and/or Cu,Zn-SOD [38]. SOD2 activity, the manganese form of SOD located in the mitochondria, was not affected by such glycation. This concept is supported by the observation of higher SOD2 activity with diabetes.

In order to better understand this discrepancy between cytosolic and mitochondrial SOD dysfunction, we tested the impact of diabetes on hepatic mitochondrial respiratory chain function. We report a decrease in state 4 respiratory rates in diabetic mice that appeared to be counterbalanced by an increased oxidative phosphorylation metabolism. In accordance with numerous studies [39-41], we also show that oxidative stress may impact on mitochondrial respiration dysfunction during diabetes. This dysfunction can result in an increased production of mitochondrial ROS, that could explain the specific overexpression and activation of Mn-SOD [42]. The low carbonylation level of proteins in the mitochondrial compartment may also be explained by the activation of Mn-SOD.

Interestingly, the uncoupled respiratory rate in both mice groups seemed to be lower than the state 3 rates. Indeed, the addition of an uncoupling agent (dinitrophenol) should lead to a permanently high rate of respiration until all the oxygen is consumed. In agreement, others previously reported such an unexpected result [43].

In parallel, we found decreased PGC1 $\alpha$ expression in diabetic 
Table 2

Glycation-modified peptides identified in HSA and AGE (HSA-MGO) by MALDI-TOF-MS peptide mapping.

\begin{tabular}{|c|c|c|c|c|c|c|}
\hline $\begin{array}{l}\text { Position of } \\
\text { sequence }\end{array}$ & $\begin{array}{l}\text { Modified } \\
\text { residue }\end{array}$ & Peptide sequence & $\begin{array}{l}\text { Peptide } \\
\text { mass }\end{array}$ & Modification & $\begin{array}{l}\text { Measured } \\
\text { mass }\end{array}$ & Modification \\
\hline \multicolumn{7}{|l|}{ HSA } \\
\hline $243-249$ & R246 & (R)LSQRFPK(A) & 875.51 & 58.03 & 933.52 & Pentosidine \\
\hline $222-229$ & K223 & (R)LKCASLQK(F) & 947.53 & 108.02 & 1055.56 & Pyrraline \\
\hline $491-499$ & R496 & (K)TPVSDRVTK(C) & 1002.56 & 58.03 & 1060.59 & Pentosidine \\
\hline $25-34$ & $\mathrm{~K} 28$ & (R)DAHKSEVAHR(F) & 1149.58 & 162.05 & 1311.63 & Fructosyl-lysine \\
\hline $338-347$ & K341 & (K)DVCKNYAEAK(D) & 1197.56 & 126.03 & 1323.59 & Fructosyl-lysine- $-2 \mathrm{H}_{2} \mathrm{O}$ \\
\hline $589-598$ & K597 & (K)ETCFAEEGKK(L) & 1198.54 & 144.04 & 1342.58 & Fructosyl-lysine- $-1 \mathrm{H}_{2} \mathrm{O}$ \\
\hline $373-383$ & K375 & (R)LAKTYETTLEK(C) & 1296.70 & 72.02 & 1368.73 & Ne-Carboxyethyl-lysine \\
\hline $549-558$ & K549 & (K)KQTALVELVK(H) & 1128.70 & 252.11 & 1380.81 & Crossline \\
\hline $427-437$ & $\mathrm{R} 434$ & (K)FQNALLVRYTK(K) & 1352.77 & 54.01 & 1406.78 & $\begin{array}{l}\text { Ne-(5-Hydro-5-methyl-4- } \\
\text { imidazolon-2-yl)ornithine }\end{array}$ \\
\hline $589-598$ & K597 & (K)ETCFAEEGKK(L) & 1198.54 & 252.11 & 1450.65 & Crossline \\
\hline $338-347$ & K341 & (K)DVCKNYAEAK(D) & 1197.56 & 270.07 & 1467.63 & $\begin{array}{l}\text { 1-Alkyl-2-formyl-3,4-glycosyl- } \\
\text { pyrrole }\end{array}$ \\
\hline 497-208 & K499 & (R)VTKCCTESLVNR(R) & 1466.71 & $58,00 / 58,03$ & 1524.71 & $\begin{array}{l}\text { Ne-Carboxymethyl-lysine/ } \\
\text { Pentosidine }\end{array}$ \\
\hline $199-210$ & K205 & (K)AACLLPKLDELR(D) & 1398.78 & 126.03 & 1524.81 & Fructosyl-lysine- $2 \mathrm{H}_{2} \mathrm{O}$ \\
\hline $585-597$ & K588 & (K)ADDKETCFAEEGK(K) & 1499.63 & 162.05 & 1661.68 & Fructosyl-lysine \\
\hline $438-452$ & K438 & (K)KVPQVSTPTLVEVSR(N) & 1639.94 & $58,00 / 58,03$ & 1697.94 & $\begin{array}{l}\text { Ne-Carboxymethyl-lysine/ } \\
\text { Pentosidine }\end{array}$ \\
\hline $287-300$ & K298 & (K)YICENQDSISSKLK(E) & 1684.82 & $58,00 / 58,03$ & 1742.83 & $\begin{array}{l}\text { Ne-Carboxymethyl-lysine/ } \\
\text { Pentosidine }\end{array}$ \\
\hline $348-361$ & R360 & (K)DVFLGMFLYEYARR(H) & 1779.89 & 39.99 & 1819.88 & $\begin{array}{l}\mathrm{Ne}-(5-H y d r o-4-i m i d a z o l o n-2-y l) \\
\text { ornithine }\end{array}$ \\
\hline $570-584$ & K581 & (K)AVMDDFAAFVEKCCK(A) & 1790.79 & 108.02 & 1898.81 & Pyrraline \\
\hline $566-581$ & K569 & (K)EQLKAVMDDFAAFVEK(C) & 1840.92 & $58,00 / 58,03$ & 1898.92 & $\begin{array}{l}\text { Ne-Carboxymethyl-lysine/ } \\
\text { Pentosidine }\end{array}$ \\
\hline $438-452$ & K438 & (K)KVPQVSTPTLVEVSR(N) & 1639.94 & 270.07 & 1910.01 & $\begin{array}{l}\text { 1-Alkyl-2-formyl-3,4-glycosyl- } \\
\text { pyrrole }\end{array}$ \\
\hline $250-264$ & K257 & (K)AEFAEVSKLVTDLTK(V) & 1650.89 & 270.07 & 1920.97 & $\begin{array}{l}\text { 1-Alkyl-2-formyl-3,4-glycosyl- } \\
\text { pyrrole }\end{array}$ \\
\hline $287-300$ & K298 & (K)YICENQDSISSKLK(E) & 1684.82 & 252.11 & 1936.93 & Crossline \\
\hline $436-456$ & R449 & (K)VPQVSTPTLVEVSRNLGK(V) & 1924.09 & 142.03 & 2066.11 & Imidazolone B \\
\hline $139-161$ & K160 & (R)LVRPEVDVMCTAFHDNEETFLKK(Y) & 2778.36 & 162.05 & 2940.41 & Fructosyl-lysine \\
\hline \multicolumn{7}{|l|}{ HSA MGO } \\
\hline $563-569$ & K565 & (K)ATKEQLK(A) & 817.48 & $58,00 / 58,03$ & 875.51 & $\begin{array}{l}\text { Ne-Carboxymethyl-lysine/ } \\
\text { Pentosidine }\end{array}$ \\
\hline $29-36$ & R34 & (K)SEVAHRFK(D) & 973.52 & 142.03 & 1115.55 & Imidazolone B \\
\hline $461-468$ & K463 & (K)CCKHPEAK(R) & 1029.46 & 108.02 & 1137.48 & Pyrraline \\
\hline $162-169$ & R168 & (K)YLYEIARR(H) & 1083.59 & 54.01 & 1137.61 & $\begin{array}{l}\text { Ne-(5-Hydro-5-methyl-4- } \\
\text { imidazolon-2-yl)ornithine }\end{array}$ \\
\hline $25-34$ & K28 & (R)DAHKSEVAHR(F) & 1149.58 & $58,00 / 58,03$ & 1207.61 & $\begin{array}{l}\text { Ne-Carboxymethyl-lysine/ } \\
\text { Pentosidine }\end{array}$ \\
\hline $237-246$ & $\mathrm{R} 242$ & (K)AWAVARLSQR(F) & 1157.65 & 54.01 & 1211.66 & $\begin{array}{l}\text { Ne-(5-Hydro-5-methyl-4- } \\
\text { imidazolon-2-yl)ornithine }\end{array}$ \\
\hline $25-34$ & K28 & (R)DAHKSEVAHR(F) & 1149.58 & 72.02 & 1221.60 & Ne-Carboxyethyl-lysine \\
\hline $35-44$ & K36 & (R)FKDLGEENFK(A) & 1226.61 & 72.02 & 1298.63 & Ne-Carboxyethyl-lysine \\
\hline $25-34$ & K28 & (R)DAHKSEVAHR(F) & 1149.58 & 162.05 & 1311.63 & Fructosyl-lysine \\
\hline $373-383$ & K375 & (R)LAKTYETTLEK(C) & 1296.70 & 72.02 & 1368.73 & Ne-Carboxyethyl-lysine \\
\hline $589-598$ & K597 & (K)ETCFAEEGKK(L) & 1198.54 & 252.11 & 1450.65 & Crossline \\
\hline $338-347$ & K341 & (K)DVCKNYAEAK(D) & 1197.56 & 270.07 & 1467.63 & $\begin{array}{l}\text { 1-Alkyl-2-formyl-3,4-glycosyl- } \\
\text { pyrrole }\end{array}$ \\
\hline $250-264$ & K257 & (K)AEFAEVSKLVTDLTK(V) & 1650.89 & 126.03 & 1776.93 & Fructosyl-lysine- $2 \mathrm{H}_{2} \mathrm{O}$ \\
\hline $348-361$ & R360 & (K)DVFLGMFLYEYARR(H) & 1779.89 & 54.01 & 1833.90 & $\begin{array}{l}\text { Ne-(5-Hydro-5-methyl-4- } \\
\text { imidazolon-2-yl)ornithine }\end{array}$ \\
\hline $570-584$ & K581 & (K)AVMDDFAAFVEKCCK(A) & 1790.79 & 108.02 & 1898.81 & Pyrraline \\
\hline $566-581$ & K569 & (K)EQLKAVMDDFAAFVEK(C) & 1840.92 & $58,00 / 58,03$ & 1898.92 & $\begin{array}{l}\text { Ne-Carboxymethyl-lysine/ } \\
\text { Pentosidine }\end{array}$ \\
\hline $169-183$ & R169 & (R)RHPYFYAPELLFFAK(R) & 1899.00 & 80.03 & 1979.02 & Argpyrimidine \\
\hline $436-456$ & R449 & (K)VPQVSTPTLVEVSRNLGK(V) & 1925.25 & 142.03 & 2066.11 & Imidazolone B \\
\hline $376-396$ & K383 & (K)TYETTLEKCCAAADPHECYAK(V) & 2518.07 & 108.02 & 2626.09 & Pyrraline \\
\hline
\end{tabular}

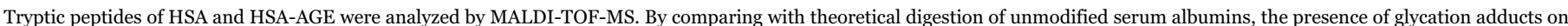

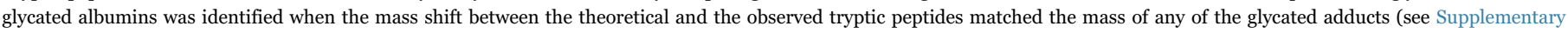
Table S2 and Fig. S4).

" Both modifications are possible on lysine and cannot simply be distinguished by mass only.

mouse livers suggesting an alteration in mitochondrial biogenesis in hepatocytes exposed to AGE that is in accordance with decreased mitochondrial content observed by Western-blotting. However, our study does not allow the establishment of a relationship between altered mitochondrial biogenesis and impaired respiratory chain activity. We suggest that the decreased basal mitochondrial oxygen consumption in diabetic mice may result in a respiratory chain slowdown where the electrons could combine more easily with oxygen 
Table 3

Glycation-modified peptides identified in MSA $(\mathrm{db} /+$ and $\mathrm{db} / \mathrm{db})$ by MALDI-TOF-MS peptide mapping.

\begin{tabular}{|c|c|c|c|c|c|c|}
\hline $\begin{array}{l}\text { Position of } \\
\text { sequence }\end{array}$ & $\begin{array}{l}\text { Modified } \\
\text { residue }\end{array}$ & Peptide sequence & $\begin{array}{l}\text { Peptide } \\
\text { mass }\end{array}$ & Modification & $\begin{array}{l}\text { Measured } \\
\text { mass }\end{array}$ & Modification \\
\hline \multicolumn{7}{|l|}{$\mathbf{D b} /+$} \\
\hline $453-460$ & R456 & (R)NLGRVGTK(C) & 844.50 & 54.01 & 898.51 & $\begin{array}{l}\mathrm{Ne}-(5-H y d r o-5-m e t h y l-4 \text {-imidazolon- } \\
\text { 2-yl)ornithine }\end{array}$ \\
\hline $230-236$ & R233 & (K)FGERAFK(A) & 854.45 & 54.01 & 908.46 & $\begin{array}{l}\text { Ne-(5-Hydro-5-methyl-4-imidazolon- } \\
\text { 2-yl)ornithine }\end{array}$ \\
\hline $453-460$ & R456 & (R)NLGRVGTK(C) & 844.50 & 80.03 & 924.53 & Argpyrimidine \\
\hline $376-383$ & K376 & (K)KYEATLEK(C) & 981.53 & $58,00 / 58,03$ & 1039.53 & $\begin{array}{l}\text { Ne-Carboxymethyl-lysine/ } \\
\text { Pentosidine* }\end{array}$ \\
\hline $213-221$ & R219 & (K)ALVSSVRQR(M) & 1015.60 & 39.99 & 1055.60 & $\begin{array}{l}\mathrm{Ne}-(5 \text {-Hydro-4-imidazolon-2-yl) } \\
\text { ornithine }\end{array}$ \\
\hline $222-229$ & K223 & (R)MKCSSMQK(F) & 1015.44 & 162.05 & 1177.49 & Fructosyl-lysine \\
\hline $25-34$ & K28 & (R)EAHKSEIAHR(Y) & 1177.61 & 144.04 & 1321.65 & Fructosyl-lysine- $-1 \mathrm{H}_{2} \mathrm{O}$ \\
\hline $224-233$ & K229 & (K)CSSMQKFGER(A) & 1229.54 & 108.02 & 1337.56 & Pyrraline \\
\hline $361-372$ & R361 & (R)RHPDYSVSLLLR(L) & 1455.81 & 142.03 & 1597.83 & Imidazolone B \\
\hline $457-469$ & K460 & (R)VGTKCCTLPEDQR(L) & 1563.73 & 72.02 & 1635.75 & Ne-Carboxyethyl-lysine \\
\hline $439-456$ & R452 & (K)APQVSTPTLVEAARNLGR(V) & 1880.03 & 39.99 & 1920.03 & $\begin{array}{l}\text { Ne-(5-Hydro-4-imidazolon-2-yl) } \\
\text { ornithine }\end{array}$ \\
\hline $491-508$ & K499 & (K)TPVSEHVTKCCSGSLVER(R) & 2045.97 & 144.04 & 2190.02 & Fructosyl-lysine- $1 \mathrm{H}_{2} \mathrm{O}$ \\
\hline $570-588$ & K584 & (K)TVMDDFAQFLDTCCKAADK(D) & 2235.97 & 162.05 & 2398.02 & Fructosyl-lysine \\
\hline $525-543$ & K527 & (K)EFKAETFTFHSDICTLPEK(E) & 2300.09 & 144.04 & 2444.13 & Fructosyl-lysine- $1 \mathrm{H}_{2} \mathrm{O}$ \\
\hline $342-360$ & K347 & (K)NYAEAKDVFLGTFLYEYSR(R) & 2286.11 & 252.11 & 2538.22 & Crossline \\
\hline $525-543$ & K527 & (K)EFKAETFTFHSDICTLPEK(E) & 2300.09 & 252.11 & 2552.20 & Crossline \\
\hline $414-434$ & K421 & (K)TNCDLYEKLGEYGFQNAILVR(Y) & 2503.23 & 72.02 & 2575.25 & Ne-Carboxyethyl-lysine \\
\hline $76-97$ & K88 & (K)TCVADESAANCDKSLHTLFGDK(L) & 2439.09 & 252.11 & 2691.20 & Crossline \\
\hline \multicolumn{7}{|l|}{$\mathbf{D b} / \mathbf{D b}$} \\
\hline $453-460$ & $\mathrm{R} 456$ & (R)NLGRVGTK(C) & 844.50 & 54.01 & 898.51 & $\begin{array}{l}\text { Ne-(5-Hydro-5-methyl-4-imidazolon- } \\
\text { 2-yl)ornithine }\end{array}$ \\
\hline $230-236$ & R233 & (K)FGERAFK(A) & 854.45 & 54.01 & 908.46 & $\begin{array}{l}\text { Ne-(5-Hydro-5-methyl-4-imidazolon- } \\
\text { 2-yl)ornithine }\end{array}$ \\
\hline $453-460$ & R456 & (R)NLGRVGTK(C) & 844.50 & 80.03 & 924.53 & Argpyrimidine \\
\hline $376-383$ & K376 & (K)KYEATLEK(C) & 981.53 & $58,00 / 58,03$ & 1039.53 & $\begin{array}{l}\text { Ne-Carboxymethyl-lysine/ } \\
\text { Pentosidine* }\end{array}$ \\
\hline $213-221$ & $\mathrm{R} 219$ & (K)ALVSSVRQR(M) & 1015.60 & 39.99 & 1055.60 & $\begin{array}{l}\text { Ne-(5-Hydro-4-imidazolon-2-yl) } \\
\text { ornithine }\end{array}$ \\
\hline $222-229$ & K223 & (R)MKCSSMQK(F) & 999.44 & 108.02 & 1107.46 & Pyrraline \\
\hline $376-383$ & K376 & (K)KYEATLEK(C) & 981.53 & 126.03 & 1107.56 & Fructosyl-lysine- $2 \mathrm{H}_{2} \mathrm{O}$ \\
\hline $222-229$ & K223 & (R)MKCSSMQK(F) & 999.44 & 144.04 & 1143.48 & Fructosyl-lysine- $1 \mathrm{H}_{2} \mathrm{O}$ \\
\hline $376-383$ & K376 & (K)KYEATLEK(C) & 982.53 & 162.05 & 1143.58 & Fructosyl-lysine \\
\hline $222-229$ & K223 & (R)MKCSSMQK(F) & 999.44 & 162.05 & 1161.49 & Fructosyl-lysine \\
\hline $25-34$ & K28 & (R)EAHKSEIAHR(Y) & 1177.61 & 144.04 & 1321.65 & Fructosyl-lysine- $1 \mathrm{H}_{2} \mathrm{O}$ \\
\hline $224-233$ & K229 & (K)CSSMQKFGER(A) & 1229.54 & 108.02 & 1337.56 & Pyrraline \\
\hline $457-469$ & K460 & (R)VGTKCCTLPEDQR(L) & 1563.73 & 72.02 & 1635.75 & Ne-Carboxyethyl-lysine \\
\hline $410-421$ & K413 & (K)NLVKTNCDLYEK(L) & 1496.74 & 162.05 & 1658.79 & Fructosyl-lysine \\
\hline $439-456$ & $\mathrm{R} 452$ & (K)APQVSTPTLVEAARNLGR(V) & 1880.03 & 39.99 & 1920.03 & $\begin{array}{l}\text { Ne-(5-Hydro-4-imidazolon-2-yl) } \\
\text { ornithine }\end{array}$ \\
\hline $491-508$ & K499 & (K)TPVSEHVTKCCSGSLVER(R) & 2045.97 & 144.04 & 2190.02 & Fructosyl-lysine- $1 \mathrm{H}_{2} \mathrm{O}$ \\
\hline $528-545$ & K543 & (K)AETFTFHSDICTLPEKEK(Q) & 2153.02 & 108.02 & 2261.04 & Pyrraline \\
\hline $570-588$ & K584 & (K)TVMDDFAQFLDTCCKAADK(D) & 2235.97 & 162.05 & 2398.02 & Fructosyl-lysine \\
\hline $528-545$ & K543 & (K)AETFTFHSDICTLPEKEK(Q) & 2153.02 & 252.11 & 2405.13 & Crossline \\
\hline $342-360$ & K347 & (K)NYAEAKDVFLGTFLYEYSR(R) & 2286.11 & 162.05 & 2448.16 & Fructosyl-lysine \\
\hline $570-588$ & K584 & (K)TVMDDFAQFLDTCCKAADK(D) & 2251.97 & 252.11 & 2504.08 & Crossline \\
\hline $342-360$ & K347 & (K)NYAEAKDVFLGTFLYEYSR(R) & 2286.11 & 252.11 & 2538.22 & Crossline \\
\hline $525-543$ & K527 & (K)EFKAETFTFHSDICTLPEK(E) & 2300.09 & 252.11 & 2552.20 & Crossline \\
\hline
\end{tabular}

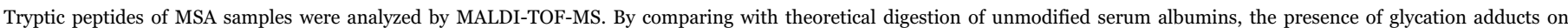

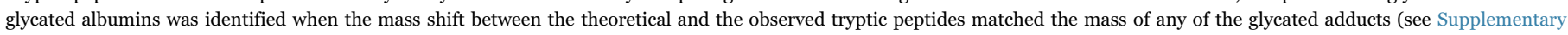
Table S2 and Fig. S4).

molecules to form superoxide anions. Superoxide anions are mainly produced by complexes I and III of the electron transport chain [44]. This alteration in mitochondrial respiratory metabolism resulting in superoxide anion production may in turn induce genomic, protein and enzymatic upregulation of Mn-SOD observed in diabetic mice. In addition, this respiratory chain slowdown seems to be due to a weak proton leak across the mitochondrial inner membrane rather than to mitochondrial complexes deficiency. Thus, the oxidative state of diabetic mice livers seems to impair intrinsic and/or extrinsic mitochondrial uncoupling leading to an overproduction of superoxide anion.

In addition, it is clearly established that the impaired redox status occurring in livers of diabetic mice can be linked to RAGE activation. Our data revealed that increased ROS production and higher RAGE expression were localized in the vicinity of the liver vasculature. These data suggest that chronic inflammation mediated by diabetes could promote ROS formation that most likely involves RAGE. In support, we found higher circulating AGE levels in $\mathrm{db} / \mathrm{db}$ mice. In order to assess AGE involvement in oxidative damage observed in livers of diabetic mice, the pathogenic role of glycated albumin as a major source of circulating AGE was considered. Here, the isolated fractions of albumin from diabetic mice exhibited typical glycation characteristics. Moreover, significant structural and biochemical differences were found between isolated albumin from $\mathrm{db} /+$ and $\mathrm{db} / \mathrm{db}$ mice in terms 

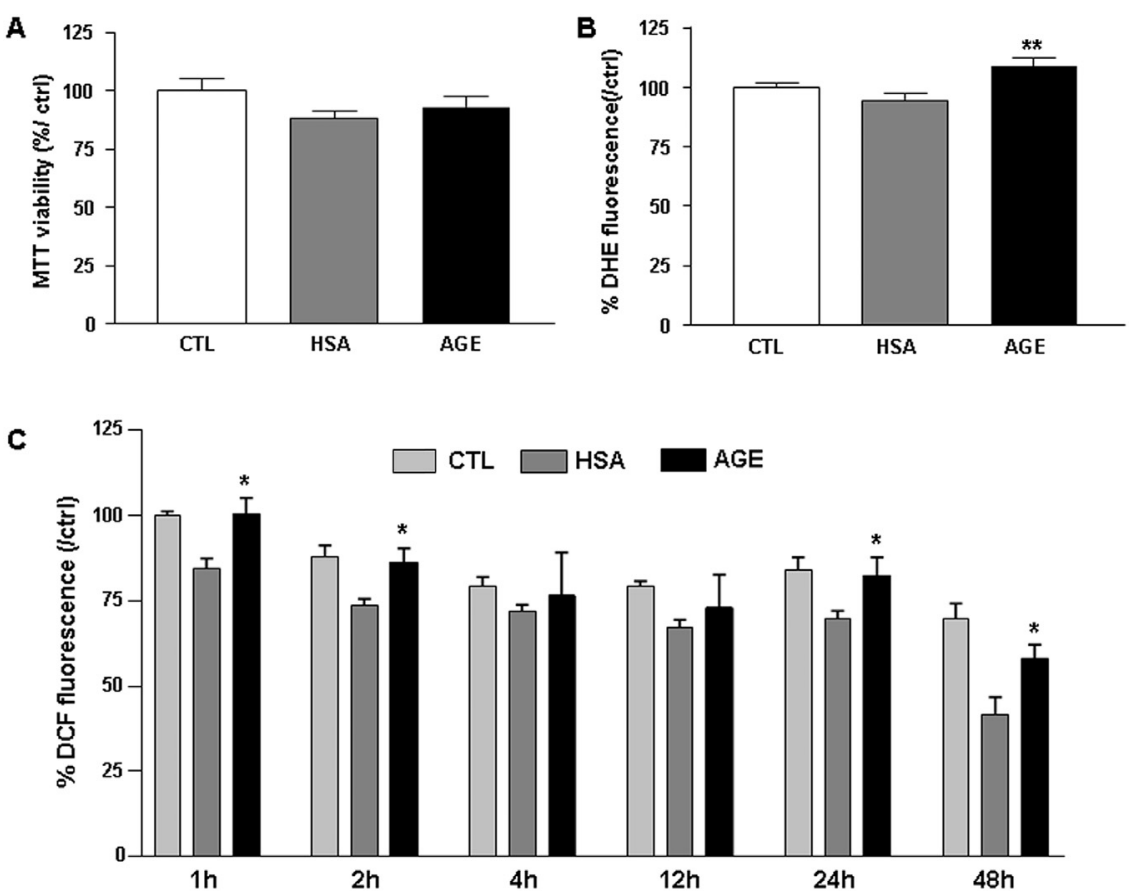

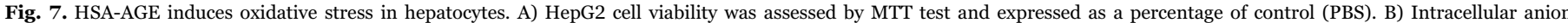

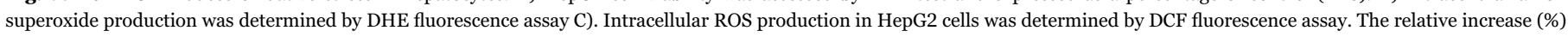

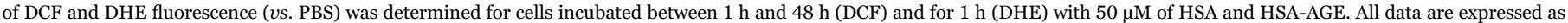
mean \pm SD of five independent experiments. " HSA-AGE $v s$. HSA: ${ }^{* * *} \mathrm{p}<0.001$.

of conformation in fluorescent tryptophan vicinity, isoelectric point, glycation level and chemical composition. Albumin from diabetic mice showed a modified isoelectric point associated with increased glycation and AGE levels that may result in alteration of protein conformation. Taken together, these findings confirm the glycated state of albumin in livers of diabetic mice and alterations in albumin biochemical parameters. Regarding the lack of difference in the average molecular mass between $\mathrm{db} /+$ and $\mathrm{db} / \mathrm{db}$ albumin, it is important to consider that there is not a linear relation between mass increase and number of modifications. This is the case as condensed molecules can undergo further oxidation and dehydration reactions leading lower molecular weight species [45]. Indeed, MSA purified from $\mathrm{db} / \mathrm{db}$ mice showed more modified residues than MSA purified from $\mathrm{db} /+$ mice. It is also possible that the number of modifications were underestimated in highly glycated proteins. In support, peptides exhibiting more than one miscleavage sites could not be detected under our experimental conditions. Of note, HSA-AGE display a lower number of modifications compared to HSA.

We also sought to reproduce these conditions with an in vitro model where human serum albumin was incubated with methylglyoxal and incubated for $24 \mathrm{~h}$ with the HepG2 cells. Our in vitro AGE model (derived from HSA) displays biochemical similarities when compared to $\mathrm{db} / \mathrm{db}$ mouse albumin samples. These findings also demonstrated a positive effect of AGE on CD36 and RAGE mRNA expression in HepG2 cells, indicating the involvement of such receptors in AGE-induced hepatocyte oxidative stress. It is however, a limitation of this study that no equivalent measurements were completed to assess RAGE and CD36 protein expression levels. These data support the conclusions reached in a recent study demonstrating mitochondrial involvement in the activation of the RAGE pathway and ROS production induced by HSA-derived AGE (unpublished data).

Although intracellular oxidative stress induced by AGE in vitro was clearly demonstrated, only catalase activity was upregulated in accordance with its expression at the transcriptional level.

In addition, LSTR proteasome activity was increased in our experimental conditions. Such discrepancies between in vitro and in vivo models may be due to an acute vs. chronic AGE exposure, respectively. Indeed, long-term exposure of vascularized tissues such as the liver to AGEs can result in protein damage, leading to enzymatic dysfunction and contributing to chronic hyperglycemia which is a characteristic of the diabetic condition. Elevated LSTR proteasome activity observed in AGE-treated cells may be considered a defense system triggered by the oxidative stress insult [46]. In support, a model of oxidative stress-dependent regulation of the proteasome was recently proposed where increased proteasomal expression is linked to specific conditions of cell exposure to oxidative stress [47]. It was also reported that exposure of the proteasome to oxidative stress leads to a biphasic response in the proteolytic activities, where "at moderate oxidant concentrations proteolytic susceptibility increases, whereas at higher oxidant concentration, a decrease (sometimes even below the "basal degradation" level) in proteolytic susceptibility occurs" [48].

Previous studies reported that oxidative stress and glycation resulted in conformational changes in albumin structure and function in vitro $[21,49,50]$, and recently in vivo by the altered fatty acid binding capacity displayed by albumin isolated from diabetic patients [51]. The present study provides novel insights into redox imbalance in the liver of diabetic/obese mice and highlights. The role of AGEs (especially glycated albumin) as putative contributors to hepatocyte dysfunction.

\section{Acknowledgement}

The authors would like to thank Dr Anne Devin (IBGC, Bordeaux, France) for her technical and scientific advice. This work was supported by the Ministère de l'Enseignement Supérieur et de la Recherche, the Conseil Régional de La Réunion and European Union («Redox » project), the Université de La Réunion. FB and $\mathrm{AD}$ are supported by a fellowship from the Conseil Régional de La Réunion et l'Europe.

\section{Appendix A. Supplementary material}

Supplementary data associated with this article can be found in the 

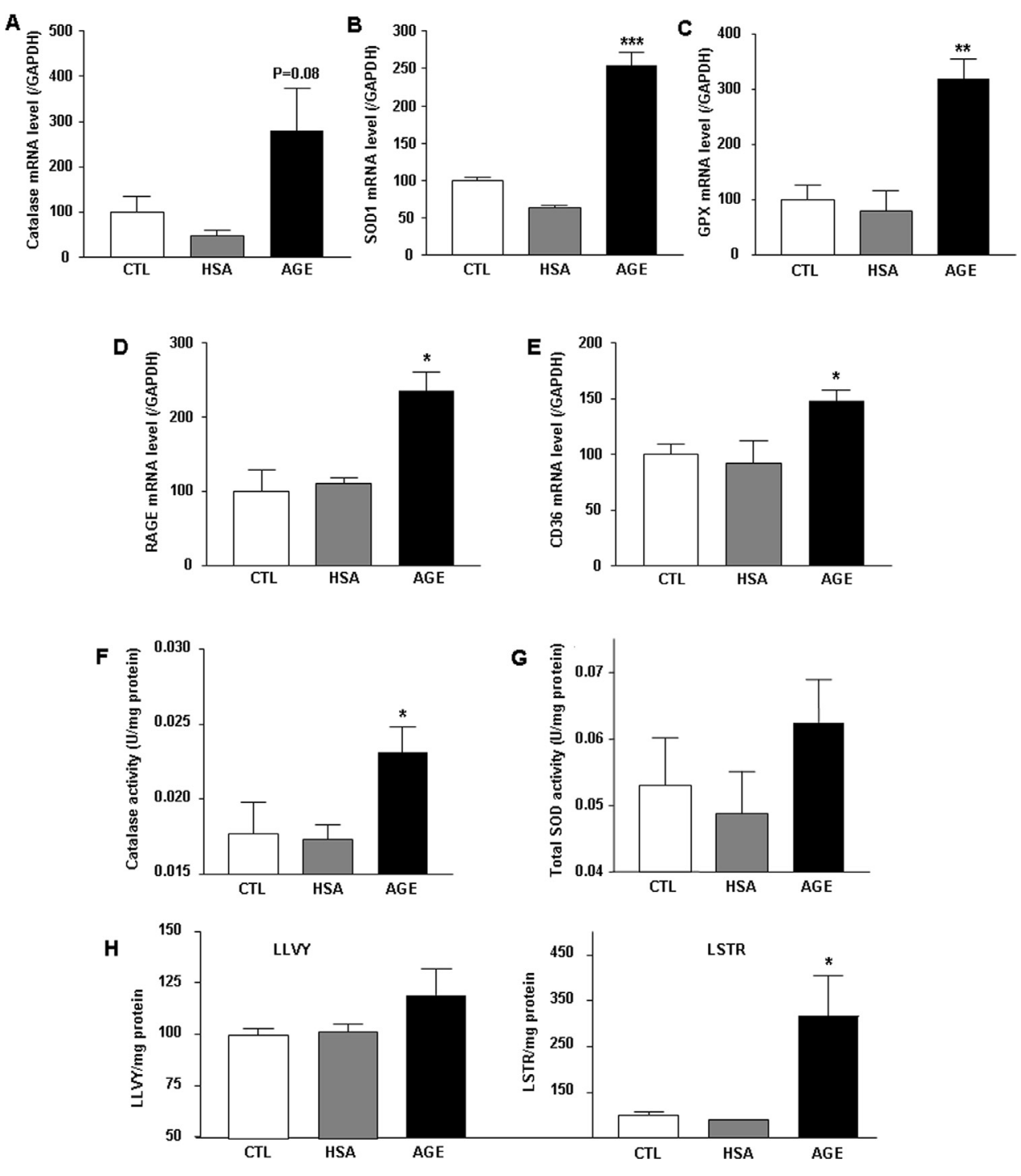

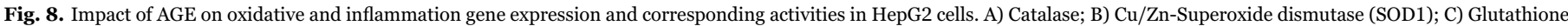

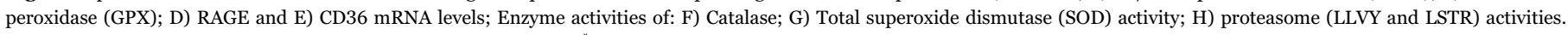
Results are expressed as mean $\pm \mathrm{SD}(\mathrm{n}=6)$ performed in triplicate. ${ }^{*}$ HSA-AGE $v$ s. HSA: ${ }^{* * *} \mathrm{P}<0.001,{ }^{* *} \mathrm{P}<0.01$ and ${ }^{*} \mathrm{P}<0.05$.

online version at http://dx.doi.org/10.1016/j.freeradbiomed.2016.11. 026.

\section{References}

[1] P. Manna, J. Das, J. Ghosh, P.C. Sil, Contribution of type 1 diabetes to rat liver dysfunction and cellular damage via activation of NOS, PARP, IkappaBalpha/NFkappaB, MAPKs, and mitochondria-dependent pathways: Prophylactic role of arjunolic acid, Free Radic. Biol. Med. 48 (2010) 1465-1484.

[2] M. Brownlee, The pathobiology of diabetic complications: a unifying mechanism, Diabetes 54 (2005) 1615-1625.

[3] M. Brownlee, The pathological implications of protein glycation, Clin. Investig. Med. 18 (1995) 275-281.

[4] M.P. Cohen, Intervention strategies to prevent pathogenetic effects of glycated albumin, Arch. Biochem. Biophys. 419 (2003) 25-30.

[5] P. Rondeau, E. Bourdon, The glycation of albumin: structural and functional impacts, Biochimie 93 (2011) 645-658.

[6] A. Vlassopoulos, M.E. Lean, E. Combet, Role of oxidative stress in physiological albumin glycation: a neglected interaction, Free Radic. Biol. Med. 60 (2013) $318-324$.

[7] M.P. Cohen, E. Shea, S. Chen, C.W. Shearman, Glycated albumin increases oxidative stress, activates NF-kappa B and extracellular signal-regulated kinase (ERK), and stimulates ERK-dependent transforming growth factor-beta 1 production in macrophage RAW cells, J. Lab. Clin. Med. 141 (2003) 242-249.

[8] J.L. Wautier, C. Zoukourian, O. Chappey, M.P. Wautier, P.J. Guillausseau, R. Cao, O. Hori, D. Stern, A.M. Schmidt, Receptor-mediated endothelial cell dysfunction in diabetic vasculopathy. Soluble receptor for advanced glycation end products blocks hyperpermeability in diabetic rats, J. Clin. Investig. 97 (1996) 238-243.
[9] K.J. Davies, Degradation of oxidized proteins by the 20S proteasome, Biochimie 83 (2001) 301-310.

[10] S.A. Harrison, A.M. Diehl, Fat and the liver-a molecular overview, Semin. Gastrointest. Dis. 13 (2002) 3-16.

[11] D. Serra, P. Mera, M.I. Malandrino, J.F. Mir, L. Herrero, Mitochondrial fatty acid oxidation in obesity, Antioxid. Redox Signal. 19 (2012) 269-284.

[12] M. Duvnjak, I. Lerotic, N. Barsic, V. Tomasic, L. Virovic Jukic, V. Velagic, Pathogenesis and management issues for non-alcoholic fatty liver disease, World J. Gastroenterol. 13 (2007) 4539-4550.

[13] S.A. Harrison, Liver disease in patients with diabetes mellitus, J. Clin. Gastroenterol. 40 (2006) 68-76.

[14] C. Zhang, X. Lu, Y. Tan, B. Li, X. Miao, L. Jin, X. Shi, X. Zhang, L. Miao, X. Li, L. Cai, Diabetes-induced hepatic pathogenic damage, inflammation, oxidative stress, and insulin resistance was exacerbated in zinc deficient mouse model, PLoS One 7 (2012) e49257.

[15] M. Roche, P. Rondeau, N.R. Singh, E. Tarnus, E. Bourdon, The antioxidant properties of serum albumin, FEBS Lett. 582 (2008) 1783-1787.

[16] R. Kakkar, S.V. Mantha, J. Radhi, K. Prasad, J. Kalra, Increased oxidative stress in rat liver and pancreas during progression of streptozotocin-induced diabetes, Clin. Sci. 94 (1998) 623-632.

[17] H. Raza, S.K. Prabu, A. John, N.G. Avadhani, Impaired mitochondrial respiratory functions and oxidative stress in streptozotocin-induced diabetic rats, Int. J. Mol. Sci. 12 (2011) 3133-3147.

[18] C.H. Park, N. Yamabe, T. Okamoto, K. Toriizuka, T. Yokozawa, Chinese prescription kangen-karyu ameliorates the development of diabetic hepatic damages via regulating oxidative stress and inflammation in the liver of $\mathrm{db} / \mathrm{db}$ mice, Biol. Pharm. Bull. 34 (2011) 383-388.

[19] C. Capeillere-Blandin, V. Gausson, B. Descamps-Latscha, V. Witko-Sarsat, Biochemical and spectrophotometric significance of advanced oxidized protein products, Biochim. Biophys. Acta 1689 (2004) 91-102. 
[20] V.B. Jovanovic, A.Z. Penezic-Romanjuk, I.D. Pavicevic, J.M. Acimovic L.M. Mandic, Improving the reliability of human serum albumin-thiol group determination, Anal. Biochem. 439 (2013) 17-22.

[21] P. Rondeau, N. Singh, H. Caillens, E. Bourdon, Oxidative Stresses Induced by glycated human or bovine serum albumins on human monocytes, Free Radic. Biol. Med. 45 (2008) 799-812.

[22] J. Rohovec, T. Maschmeyer, S. Aime, J.A. Peters, The structure of the sugar residue in glycated human serum albumin and its molecular recognition by phenylboronate, Chemistry 9 (2003) 2193-2199.

[23] A. Guerin-Dubourg, A. Catan, E. Bourdon, P. Rondeau, Structural modifications of human albumin in diabetic context, Diabetes Metab, 38 (2012) 171-178.

[24] J. Baraka-Vidot, A. Guerin-Dubourg, F. Dubois, B. Payet, E. Bourdon, P. Rondeau, New insights into deleterious impacts of in vivo glycation on albumin antioxidant activities, Biochim. Biophys. Acta 1830 (2013) 3532-3541.

[25] B. Paradela-Dobarro, B. Rodino-Janeiro, J. Alonso, S. Raposeiras-Roubin, M. Gonzalez-Peteiro, J. Gonzalez-Juanatey, E. Alvarez, Key structural and functional differences between early and advanced glycation products, J. Mol. Endocrinol. 56 (2016) 23-37.

[26] D. Bar-Or, E. Lau, J.V. Winkler, A novel assay for cobalt-albumin binding and its potential as a marker for myocardial ischemia-a preliminary report, J. Emerg. Med. 19 (2000) 311-315.

[27] H.D. Guthrie, G.R. Welch, Determination of intracellular reactive oxygen species and high mitochondrial membrane potential in Percoll-treated viable boar sperm using fluorescence-activated flow cytometry, J. Anim. Sci. 84 (2006) 2089-2100.

[28] A.L. Tappel, Glutathione peroxidase and hydroperoxides, Methods Enzymol. 52 (1978) 506-513.

[29] G.R. Faloona, P.A. Srere, Escherichia coli citrate synthase. Purification and the effect of potassium on some properties, Biochemistry 8 (1969) 4497-4503.

[30] B.S. Kirby, A. Bruhl, M.N. Sullivan, M. Francis, F.A. Dinenno, S. Earley, Robust internal elastic lamina fenestration in skeletal muscle arteries, PLoS One 8 (2013) e54849.

[31] S. Austin, J. St-Pierre, PGC1alpha and mitochondrial metabolism-emerging concepts and relevance in ageing and neurodegenerative disorders, J. Cell Sci. 125 (2012) 4963-4971.

[32] H.M. Knott, B.E. Brown, M.J. Davies, R.T. Dean, Glycation and glycoxidation of low-density lipoproteins by glucose and low-molecular mass aldehydes. Formation of modified and oxidized particles, Eur. J. Biochem. 270 (2003) 3572-3582.

[33] F. Giacco, M. Brownlee, Oxidative stress and diabetic complications, Circ. Res. 107 (2010) 1058-1070.

[34] K. Hamden, S. Carreau, M.A. Boujbiha, S. Lajmi, D. Aloulou, D. Kchaou, A. Elfeki, Hyperglycaemia, stress oxidant, liver dysfunction and histological changes in diabetic male rat pancreas and liver: protective effect of 17 beta-estradiol, Steroids 73 (2008) 495-501.

[35] F.C. Di Naso, A. Simoes Dias, M. Porawski, N.A. Marroni, Exogenous superoxide dismutase: action on liver oxidative stress in animals with streptozotocin-induced diabetes, Exp. Diabetes Res. 2011 (2011) 754132.

[36] B. Friguet, Oxidized protein degradation and repair in ageing and oxidative stress, FEBS Lett. 580 (2006) 2910-2916.
[37] H. Bakala, M. Hamelin, J. Mary, C. Borot-Laloi, B. Friguet, Catalase, a target of glycation damage in rat liver mitochondria with aging, Biochim. Biophys. Acta 1822 (2012) 1527-1534.

[38] J. Fujii, T. Myint, A. Okado, H. Kaneto, N. Taniguchi, Oxidative stress caused by glycation of $\mathrm{Cu}, \mathrm{Zn}$-superoxide dismutase and its effects on intracellular components, Nephrol. Dial. Transplant. 11 (Suppl 5) (1996) 34-40.

[39] C. Bonnard, A. Durand, S. Peyrol, E. Chanseaume, M.A. Chauvin, B. Morio, H. Vidal, J. Rieusset, Mitochondrial dysfunction results from oxidative stress in the skeletal muscle of diet-induced insulin-resistant mice, J. Clin. Investig. 118 (2008) 789-800.

[40] J.M. Curtis, P.A. Grimsrud, W.S. Wright, X. Xu, R.E. Foncea, D.W. Graham, J.R. Brestoff, B.M. Wiczer, O. Ilkayeva, K. Cianflone, D.E. Muoio, E.A. Arriaga, D.A. Bernlohr, Downregulation of adipose glutathione S-transferase A4 leads to increased protein carbonylation, oxidative stress, and mitochondrial dysfunction, Diabetes 59 (2010) 1132-1142.

[41] B.I. Frohnert, D.A. Bernlohr, Protein carbonylation, mitochondrial dysfunction, and insulin resistance, Adv. Nutr. 4 (2013) 157-163.

[42] M.P. Murphy, How mitochondria produce reactive oxygen species, Biochem. J. 417 (2009) 1-13.

[43] G. Serviddio, F. Bellanti, A.M. Giudetti, G.V. Gnoni, N. Capitanio, R. Tamborra, A.D. Romano, M. Quinto, M. Blonda, G. Vendemiale, E. Altomare, Mitochondrial oxidative stress and respiratory chain dysfunction account for liver toxicity during amiodarone but not dronedarone administration, Free Radic. Biol. Med. 51 (2011) 2234-2242.

[44] J.F. Turrens, Superoxide production by the mitochondrial respiratory chain, Biosci. Rep. 17 (1997) 3-8.

[45] A. Lapolla, D. Fedele, R. Seraglia, S. Catinella, L. Baldo, R. Aronica, P. Traldi, A new effective method for the evaluation of glycated intact plasma proteins in diabetic subjects, Diabetologia 38 (2013) 1076-1081.

[46] F. Boyer, N. Diotel, D. Girard, P. Rondeau, M.F. Essop, E. Bourdon, Enhanced oxidative stress in adipose tissue from diabetic mice, possible contribution of glycated albumin, Biochem. Biophys. Res. Commun. 473 (2016) 154-160.

[47] M. Pajares, N. Jimenez-Moreno, I.H. Dias, B. Debelec, M. Vucetic, K.E. Fladmark, H. Basaga, S. Ribaric, I. Milisav, A. Cuadrado, Redox control of protein degradation, Redox Biol. 6 (2015) 409-420.

[48] T. Grune, K. Merker, G. Sandig, K.J. Davies, Selective degradation of oxidatively modified protein substrates by the proteasome, Biochem. Biophys. Res. Commun. 305 (2003) 709-718.

[49] E. Bourdon, N. Loreau, D. Blache, Glucose and free radicals impair the antioxidant properties of serum albumin, Faseb J. 13 (1999) 233-244.

[50] K. Oettl, R.E. Stauber, Physiological and pathological changes in the redox state of human serum albumin critically influence its binding properties, Br. J. Pharmacol. 151 (2007) 580-590.

[51] D. Blache, E. Bourdon, P. Salloignon, G. Lucchi, P. Ducoroy, J.M. Petit, B. Verges, L. Lagrost, Glycated albumin with loss of fatty acid binding capacity contributes to enhanced arachidonate oxygenation and platelet hyperactivity: relevance in patients with type 2 diabetes, Diabetes 64 (2015) 960-972. 